\title{
Pauline Donceel-Voûte
}

\section{The (In)Visible Evil in Sacred Space: Codes, Keys and Clues to Reading Its Image.}

Representation is a creation of presence, a rendering present. The power of the image and of iconic re-presentation lies in this production of a new, or renewed, reality and in the bringing forth, communicating and exchanging of meaning it will generate. This implies that, should evil in whatever guise be figured by the artist it is made present and ready to cause havoc in its new environment.

'Letting Evil loose' being the ultimate danger, artefacts have, since time immemorial, developed a language of prevention, to secure and protect them and their surroundings from the presence of the possible obnoxious intruder. They address it by a variety of dissuasive maneuvers, discursive, trap-like or simply dismissive, these being called apo-tropaia which literally translates as warders off. The sheer size of certain artefacts makes them obviously, ostentatiously, ontologically visible. Others, unobtrusively, as if adapting their tactics to the sly, malicious ways of the jealous Devil, act discreetly, quite invisibly, though with comparable weapons. Either way, though Evil is as yet invisible and not patently present, they render its threat perceptible.

When evil is present and visible in words and/or shape we will find that the strategy is of another nature, warring, fighting and victorious.

Our first goal is to identify some of the most striking and long-lasting iconographic strategies, in particular those in sacred surroundings, and to see how they function, in order to sort out what has and what has not been made visible, and why.

\section{Apotropaia against an invisible evil}

\subsection{Guards: aggressive, inquisitive, hybrid or/and multiple}

The best-known category of 'warders-off', since the earliest Antiquity, is that of guardian figures, animal, human and hybrid.

What characterizes the lions, alongside the long-horned bulls composing the entrance portico to the Tell Halaf temple (now the entrance to the Aleppo Museum), is not only that they are huge and will not be moved easily but that they have bared their teeth (fig. 1). This is a natural and age-old sign of aggressiveness - such also as sticking out tongues or hands on haunches or legs bent and prepared to jump. Bared

Ә Open Access. (c) 2018 Pauline Donceel-Voûte, publiziert von De Gruyter. (cc) BY-NC-ND Dieses Werk ist lizenziert unter der Creative Commons Attribution-NonCommercial-NoDerivatives 4.0 Lizenz. 


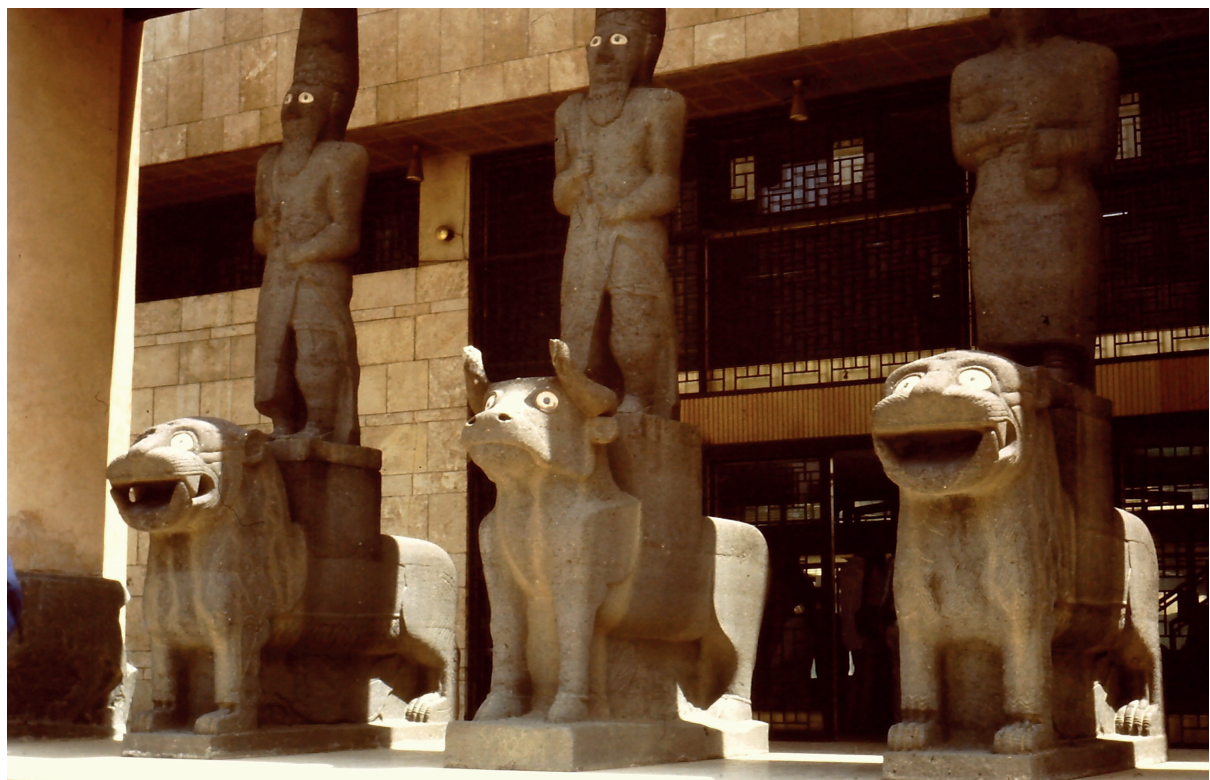

Fig. 1: Animal and human guards, basalt and inlaid shell, Tell Halaf temple portico, set up in the Aleppo Museum (@ Donceel 2000).

teeth in wide open mouths ${ }^{1}$ ready to growl and attack are not the only clue as to how the enormous double lion bases of the Marash temple also function; the black color of the dense basalt they are hewn out of is equally awe inspiring. The lions that protect the imposing Phoenician sarcophagus of Hiram-Qabr Hiram -, are also typical apotropaia, all the more as there are five of them - one at each corner and one lying on the cover. The male and female ceramic lions of the gate of the Nisaba and Haia temple, in Tell Harmal / Shaduppum (Iraq), have immense and protruding open jaws with very sharp teeth. While they look straight ahead, their large shell-like ears are wide open on both sides thus showing all-round inquisitiveness. ${ }^{2}$

1 Inversely, the suave smiles with softly closed lips, that most deities, saintly figures and angels carry in the decorative programs of Graeco-Roman temples, of churches and of homes, convey goodwill and concord.

2 Guide-Book to the Iraq Museum 1976, ill. 27; Amiet 1977, ill. 2 and 446, see 516. The majority of our examples have been chosen for their celebrity and have previously been so widely commented upon and published that specific information as to bibliography or reproductions are not given. Each of our commentaries, which concern the specific powers and workings of a category of images, could equally well have been applied to a number of other artefacts, well-known or not. This author's intention being that the given keys and clues are to be understood as part of an, often universal, vocabulary, they are to be used - and tested - for individual identifications, be it in other chronological and geographical contexts than the middle eastern to the western sphere in historical, pre-modern times, as formerly understood by the organizers of this colloquium. 


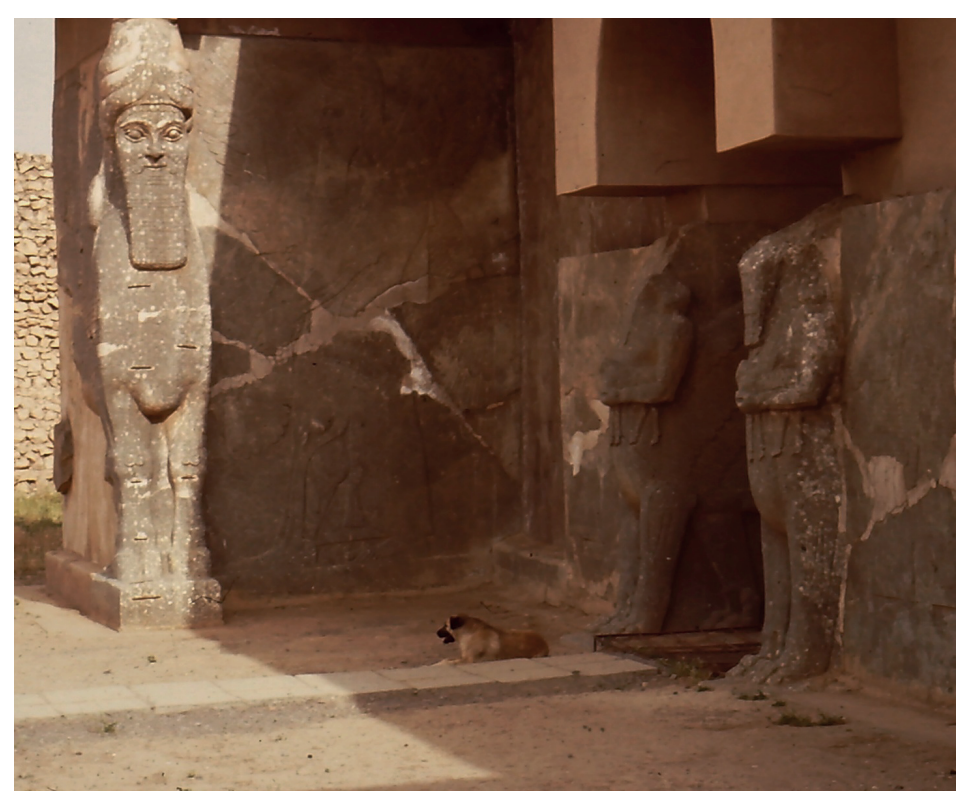

Fig. 2: Nimrud (Kalakh) gate guards; anthropomorphic winged bull with godly tiara and winged lioncentaurs, 9th c. B.C. (๑ Donceel 1977).

The same goes for the enormous standing riders from Tell Halaf (fig. 1): the beasts are standing firmly on all fours, ready to move forward, with sharp horns, teeth and claws. They have riders who are warriors at arms as well as keepers, which the white shell and bitumen inlay of their bright wide-open eyes makes quite clear. As to their size and their exaggerated massive forms, they are an obvious rhetorical device.

They all face the newcomer with aggressive fearlessness and vigor. Once passed, you may walk confidently alongside, as they are no more en face but in profile (with an eventual fifth leg to make both viewing angles credible as to their message). The view in profile as it is experienced in, for example, the Dur Sharrukin-Khorsabad figures and their various parallels such as the figures from Nimrud (fig. 2), preceding the entrance from the time of Assurbanipal II, with their legs stretched wide, conveys a dynamic energy, all the more active as there will be more suggestions of movement, such as the flying side-curls of the wig worn by the bull's human and divine head in Khorsabad (now in the Louvre).

A remarkable majority of these and other guardian figures are both animal and human. They are hybrids. The clue to this iconographical choice, particularly recurrent in Antiquity is that these composite beings are an adding up of the intelligence, the virtues, the capacities of each of their components. A famous and most efficient five-fold, or rather, six-fold hybridity is that of those weighty but beautiful shining alabaster colossi of the Khorsabad gates, already referred to, and their parallels: the 
bulls, winged, anthropomorphic, and crowned with the godly tiara, function as solid doorkeepers, if not doorposts. ${ }^{3}$

Through time, these combinations lose their positive meaning, as we understand from a number of texts that formulate the mentality of the western Middle Ages. Hybrids tend to be considered as negative, a subtraction instead of a sum: they are only part of a human being + part of a bird + part of a beast... As such they are monsters and diabolical, in the sense that they are not conforming to the harmony of divine creation. ${ }^{4}$ Only such hybrids as are composed of a human (or some other highly intelligent being) and of wings - such as angels, or Muhammad's horse Buraq -, seem to be tolerated and to keep having a positive role to play in sacred art. This is due, most probably, to the fact that the wings will allow them to approach the heavens and the heavenly dwellers for whom they carry messages.

However, throughout the Christianized western Middle Ages, other, very ancient hybrids continue operating as they did in Antiquity. Such is the case with the frightening gargoyles springing forth from the gutters, spires and towers of innumerable gothic churches. Their proposed mode of action is analogous to that of the awe-inspiring, polymorphic ancient gate-keepers already met with, their special mission being the protection of the building's roofs and outside walls. Inside the building, the fantastic grimacing creatures composing Romanesque capitals can be understood in the same way. ${ }^{5}$

The multiple natures of hybrids are meant to allow them to face the most varied enemies.

Outstretched necks and eager faces, big eyes, wide-open beaks and mouths clearly indicate that some feared occurrence may come out from anywhere and has to be energetically countered. Indeed, a notable feature of these grotesques is the variety of their orientations. They look left and right, up and down, or combine axes as in the three-headed Cerberus-like hound high up on Notre-Dame de Paris' walls. Even a rear view may be organized in just one figure, as is shown, thousands of years earlier, by the crocodile-head counterweight of a striking Egyptian pectoral collar now in the Louvre which bares its rows of teeth at one coming upon from behind. ${ }^{6}$

Evidently, the more watchers there are, each one on the look-out in as many different directions, the better. Thanks to their vigilance they will keep not only the build-

3 See Parrot 1960, fig. 29-35 and Parrot 1961, 16 (fig. 25), for these and other composite guards. Another multiple and thus all the more potent hybridity, is that of the apotropaic Bês, warrant of fertility - as his erect phallus shows - endowed, in some remarkable artefacts, with the united powers of all the gods whose different animal heads ornament and multiply the divine powers of the Bês figure: see Dunand/Zivie-Coche 2004, 17-20.

4 See Lascaux 1973.

5 See infra §IV. Evil visible.

6 See internet site cartelfr.louvre.fr/cartelfr/visite $>$ Par Départements : Antiquités égyptiennes > Égypte pharaonique $>$ Recherche avancée $>\left(N^{\circ}\right.$ d'inventaire $)$ : E11520 >lancer la recherche to view picture and commentary (last accessed: 12/2015 and 4/12/2017). 
ing they are part of but also the whole area around them, such as most of central Paris for the Notre-Dame gargoyles or the broad and busy thoroughfares around San Paolo fuori le mura in Rome, where it is the sculptures of the purely human figures of the Apostles and Jesus standing on the façades' top balustrades that bless and protect.

\subsection{Light Against the Dark Forces}

Light is a potent apotropaion. Our bright streetlights provide confidence at night, when 'the dark forces' roam freely. Bright colors, golden or silver haloes and glorious rays play around benign divinities, god-kings, saints and all types of benevolent figures $^{7}$ for them to be understood as such. The nimbus not only conveys the, particularly spiritual, intensity and strength of the personality it encloses, but equally, in a centrifugal dynamic, it sends its aura around, inside and outside the work of art, that is in the space of the viewers, our space.

These sources of light ward off the untrustworthy gloom even in sacred areas though, again, particularly that of the gates, doors and other entrances. Such is the seven-armed candelabra, with all seven little lamps lit, that sculptors have carved in door lintels and jambs or that mosaicists have laid in the pavement of thresholds of, mainly, synagogues. The colourful entrance carpet of the Apamea-on-the-Orontes synagogue, dating back to the second half of the $4^{\text {th }}$ century, found under the probably late $5^{\text {th }}$ century Atrium Church, ${ }^{8}$ sends small bright red flames straight towards where an entrance of the hall must have been (fig. 3). Small globular lamps in the contemporaneous mosaic menorah on the threshold of the, equally $4^{\text {th }}$ century, synagogue of Philippopolis / Plovdiv in Bulgaria, ${ }^{9}$ function in the same way as the Apamea candelabra. ${ }^{10}$

7 The halo is not only that of the sun and moon (personified or not) or of various saintly figures but also of personifications of Virtues or of the Seasons, and the Months etc., inasmuch as each of these is a strong occurrence and has inherent powers; it carries a centripete and centrifugal message when set around a head or whole body which says something like: 'this person has a strong, especially spiritual, personality whose aura shines out towards all else inside and outside the planes of the work of art it is represented in, including us, the viewers'.

8 Napoleone-Lemaire/Balty 1969, 9.

9 Kesjakova 1989, 20-33.

10 For a series of formulae associating light with goodness, beauty, health, truth, concord and life, against darkness as obscure, sickly, ugly and deathly in the Acts of Thomas, see Playoust 2014, 40-45. 


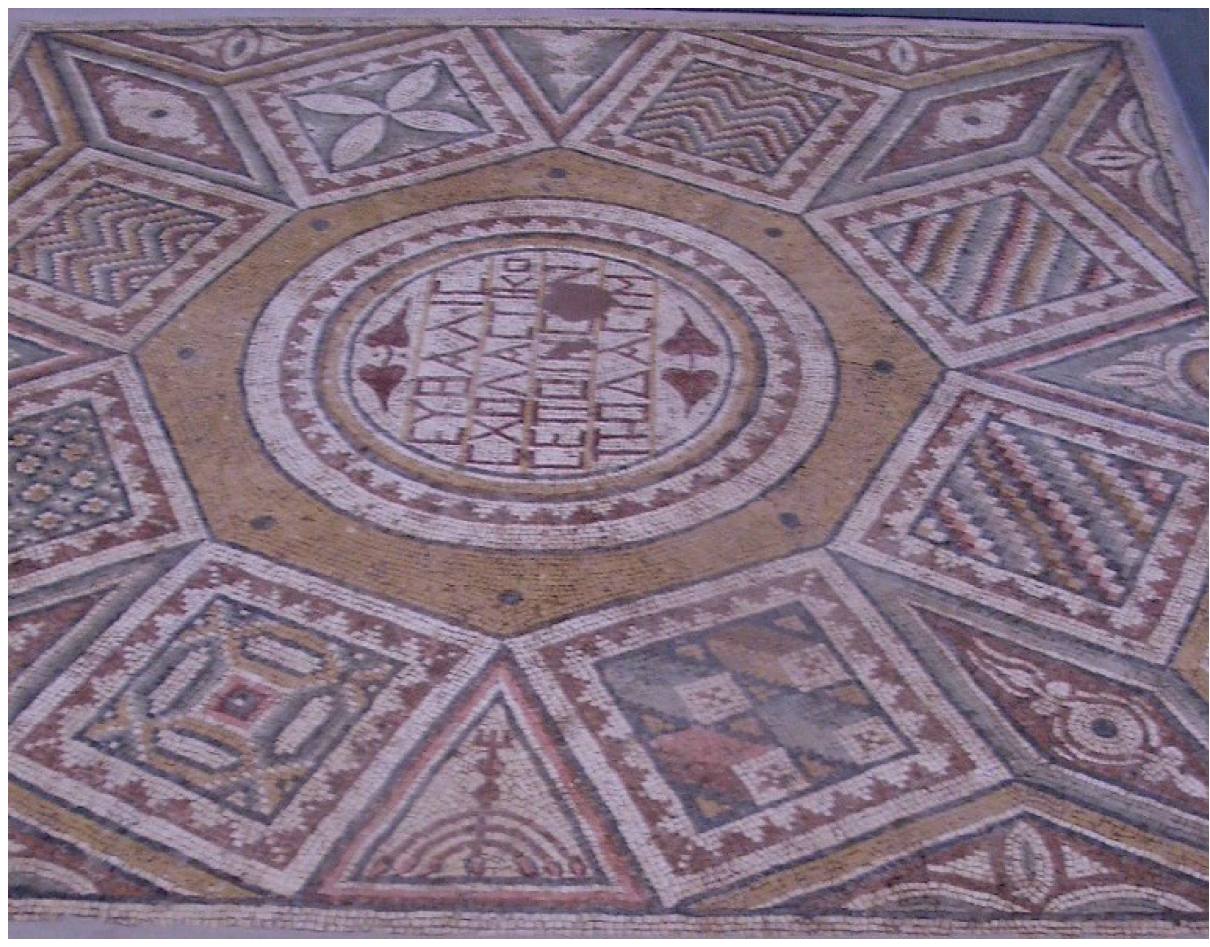

Fig. 3: Lighted candelabra in the mosaic pavement threshold of the Apamaea-on-the-Orontes synagogue, mid-4th c. Musées Royaux d'art et d’histoire, Bruxelles. (๔ Donceel 2012).

\subsection{Protective Gestures from up High}

A recurrent feature of a number of haloed, light bringing, saintly figures is their ostentatiously protective gestures: passing the arm over the shoulders or laying the palm of the hand on them - especially the right one, i.e. signaling the 'righteous', as should be underlined again and again. Such are, however diverse in time and place, the king and queen on the back of the inlaid golden throne from Tuth Ankh Amon's tomb, receiving the kindly hands of the sun's rays, ${ }^{11}$ or the children and other donors of the mosaic panels in the Saint-Demetrios church in Saloniki (fig. 4) or abbot Menas in the large Bawit icon in the Louvre collections (fig. 5), or the bishop Marianos, or

11 The back of the throne, the part of the piece of furniture one leans against and on has been extensively published and illustrated, have little hands at the end of each ray to land on the head and shoulder of the king and queen; the same motif and same actors, in alabaster and therefore without the glorious blue-and-gold colour scheme, shows Akhnaton and Nefertiti offering with the welcoming rays ending in little curved hands towards them and their offerings (Cairo Museum) (DesrochesNoblecourt 1961, ill. 63). 

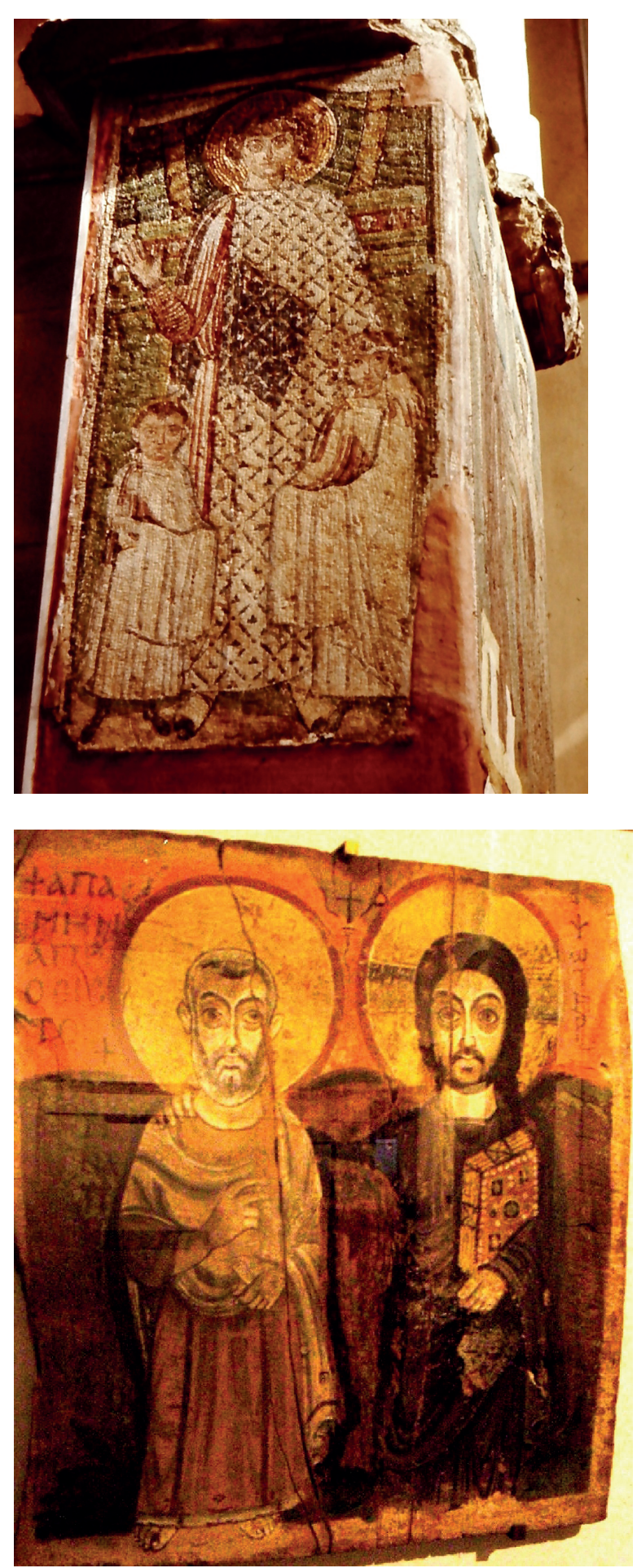

Fig. 4: Saloniki, Saint-Demetrios protecting and greeting, church pillar mosaic. (@ Donceel 1975).
Fig. 5: Coptic icon with Apa Menas blessing, protected by Jesus Christ. (@ Donceel 2014). 
the Nubian prince, and the king's mother protected by the haloed Mother of God and Child Jesus in the Faras cathedral wall paintings. ${ }^{12}$ The hand-on-the-shoulder gesture is familiar to us in particular since the numerous Memoria altar panels of the $16^{\text {th }}$ and $17^{\text {th }}$ centuries, many of them triptychs, in which the painted couple kneel left and right of the biblical scene, with the recommendatory hand of their patron saint weighing on their back, their head, their shoulder or their upper arm. ${ }^{13}$ The protection thus conferred is generally clearly transmitted also to the viewers, among whom the donor, standing outside the planes of the artefact: this is done by the protected person in the artefact, by ways of a blessing, an open hand or the direction of faces and eyes towards us, who are face to face with, but outside, that artefact.

Arms or wings wide open behind one or a group of persons also mean that they are receiving a protection. This protection is not only in the image but it originates from afar-on the reverse side of the wall or of the artefact and from the heavens above them... -, and takes us, the viewers, up in their embrace.

\subsection{A show of Shields and Weapons Dissuading from Attack}

To boast influential, powerful patrons is an excellent strategy of dissuasion. So is making a show of one's weapons and armed forces. Art can play that part by making an iconographic boast of the building's or the owner of the artefact's strength against 'the enemy', as many a frieze of defensive or offensive artefacts, weapons and armour or a panel with a choice of shields, harpoons, even knives on the walls and door- or window-frames of tombs and temples remind us.

Even in the mosaic or inlaid floor of a church one may find here a pelta ${ }^{14}$, there some other heavier shield, or two crossed shields or lances, or a trident, a scythe or a sickle ${ }^{15}$, or a double axe in each of four corners of panels always situated near to a door or an intercolumniation considered in need of 'protection' at the time of the lay-out. ${ }^{16}$

12 Michalowski/Corteggiani/Roccati 1968/1994, ill. 195.

13 The gesture is one of 'giving protection to' and also of 'taking possession of', as appears quite clearly, though with an inverse, negatively modified meaning, in Giotto's Scrovegni Chapel painting, where it is the devil's right hand that is laid on the right arm and shoulder of Judas, who is receiving the heavy purse from the chief priests and elders in payment for his betrayal of Jesus. The devil's figure, that of Judas' patron in fact, is cut in half by the left-side frame, thus not letting him roam freely through the picture and the chapel's space (see §IV).

14 Donceel-Voûte 1988, 72 and fig. 404; pelta in the Dibsi Faraj Citadel church (Syria $5^{\text {th }}$ c.), and in Saint-Christopher at Qabr Hiram (Phoenicia $6^{\text {th }} \mathrm{c}$.).

15 Donceel-Voûte 1988, 370 for double axes in the Khalde-Choueifat church (Phoenicia $5^{\text {th }}$ c.) and ibid., fig. 62, for a sickle between two ducks in an intercolumnar panel in Hawarte.

16 Donceel-Voûte 2014, 354-355, fig. 11-14. 


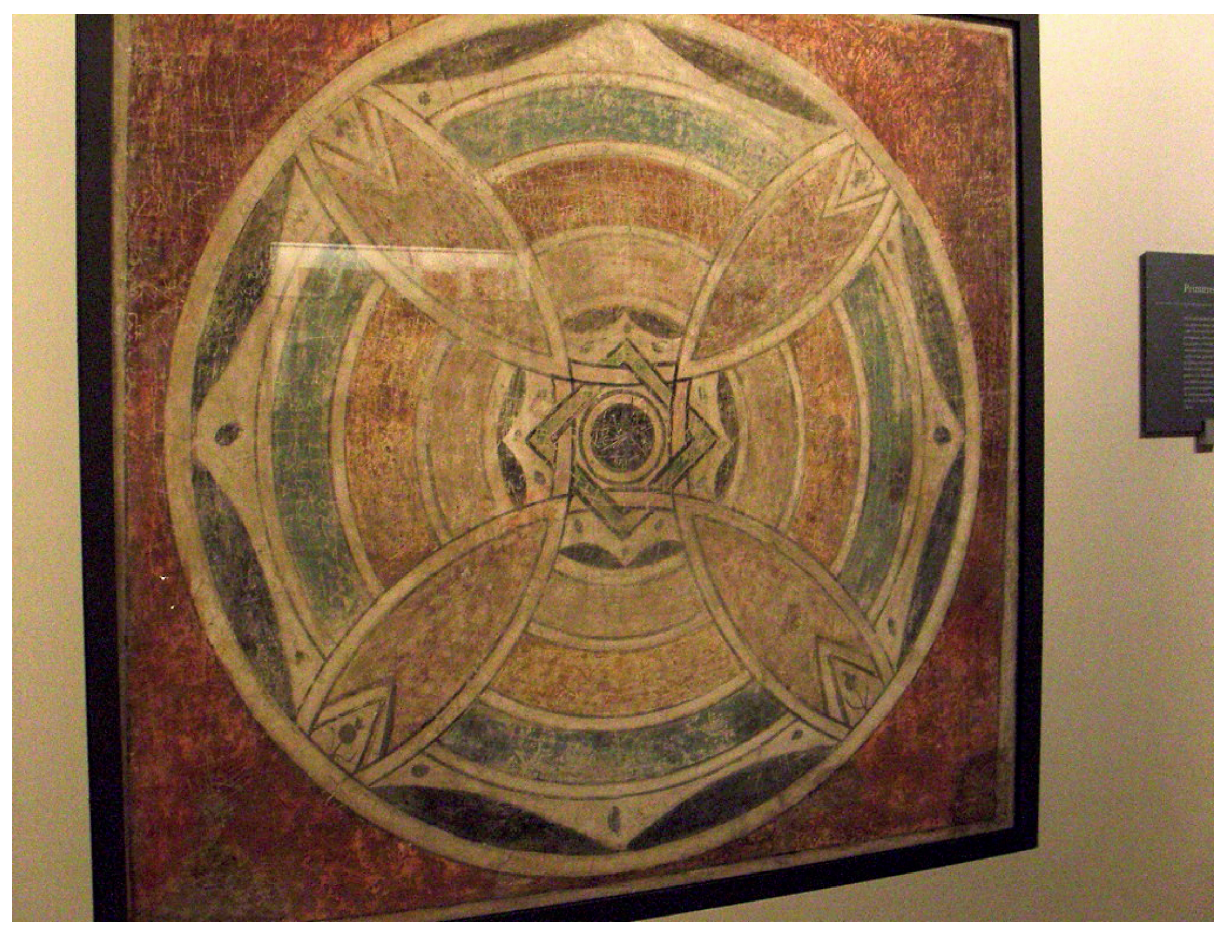

Fig. 6: Large painted shield on the walls of the South Church in Bawit, reconstruction in the Louvre Museum. (@ Donceel 2014).

The South basilica church of the Saint Apollo monastery in Bawit - the model and restored wall paintings of which can currently be visited in the special Bawit site display rooms in the Louvre museum - had walls protected by vast round shields of brightly coloured geometric and interlace ${ }^{17}$ motifs that cover the whole mass of these walls (fig. 6).

In this category of defensive armament, one cannot fail to give a prominent place to the embossed shields on a number of the most elaborate and famous khatchkars (that is cross-stone stelae), so typical of the medieval Armenian Christian art treasures (fig. 7).

The equipment of warrior gods and soldier saints plays a spectacular part in their dissuasive show. Not only do they have a variety of lances, swords and shields, but their garments are extremely richly and colorfully embellished with embroideries and appliqués, precious belts and ornate borders. Mounted warrior saints ${ }^{18}$, such as the saint Sisinnios known from Jean Clédat's watercolor of chapel XVII in Bawit (fig. 8),

17 See §II for the category of rope-like, braided, interlaced and interloped motifs.

18 See Walter 2003; also Fauth 1999, 401-425. My observations concern those characteristics that have not previously been high-lighted or commented upon. 


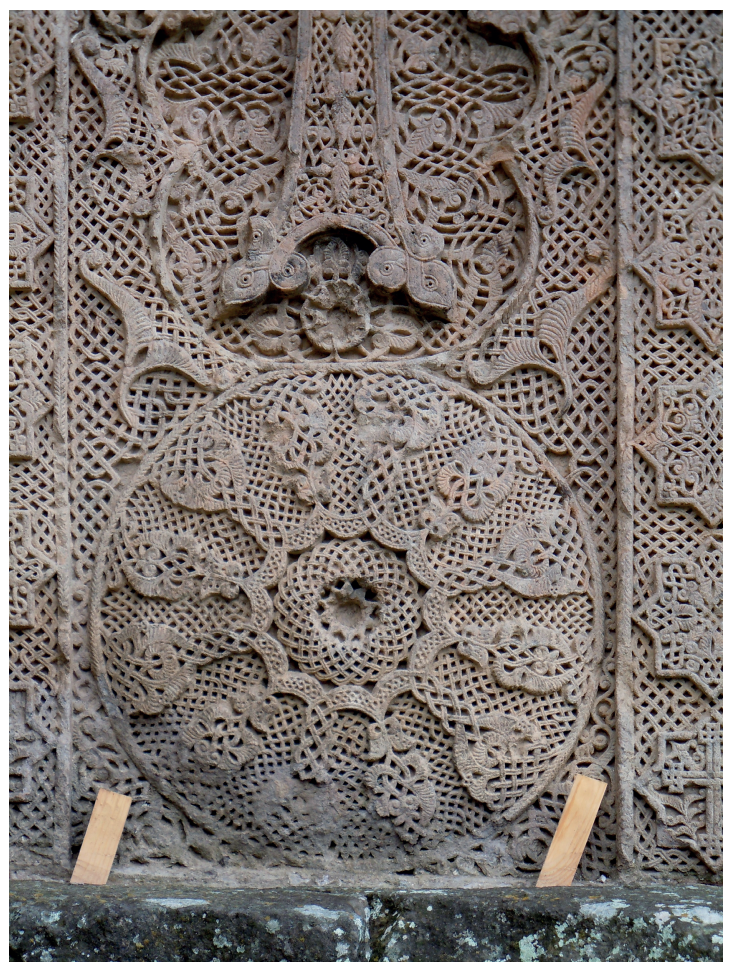

Fig. 7: Armenian khatchkar / cross-stone with shield motif, stone lace-work by Master Poghos, Goshavank. (@ Donceel 2014).

ride high and vigorous horses, with thrashing tails and flying manes; their elaborate trappings are luxuriously ornamented with jewels, ribbons and sometimes little bells so as to elegantly frighten away some lurking malevolent spirit. Noise, percussion instruments and other loud music are, indeed, part of the apotropaic accessories. Such a display of riches is meant to convey the wealth and therefore the power which the saint or god, and the entire interior decoration with them, possess to combat evil. This feature and its message, that richness means power to enforce, is recurrent in art and crucial for our subject, though rarely taken into account as such. ${ }^{19}$

Equally characteristic of the post-classical warrior heroes' and saints' iconography is that their cape, the military chlamys, is systematically billowing behind and above them as if it were caught by the speed of their race and their action through time and space.

19 Bracelets and other jewels set in gold with incredibly large stones, as well as richly adorned and colored clothes, all say that wealth is power, the power of the image that makes up for the viewer's helplessness (see § III). 


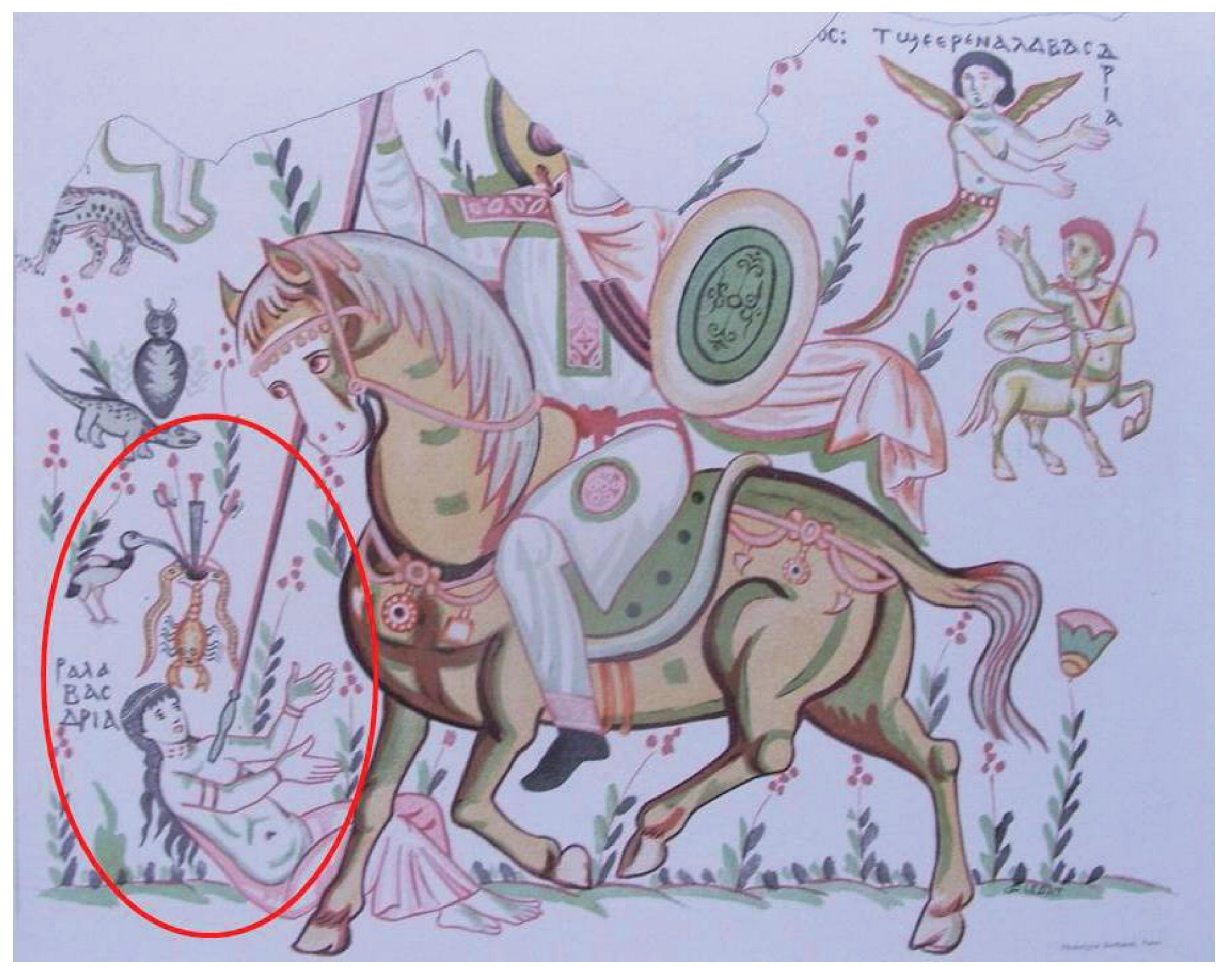

Fig. 8: Coptic wall painting of saint Sisinnios, his foes and his companions, as discovered in Chapel XVII in Bawit. (Clédat 1904, pl. LVI).

The same energy issues from the two hybrids on the right of the saintly rider in Bawit (fig. 8). The centaur equally wears a flying cape, and his energy develops in all directions as his fore leg is poised ready for action towards the right, while his arms and face are turned left. He carries a harpoon and, it seems, a bow in his left hand. Meanwhile, his right arm and open hand are lifted high in a gesture which accompanied the 'Ave Caesar' salute in Roman antiquity, and which we well know from its being up-dated in the $20^{\text {th }}$ century: that of acclamation. It was also in use outside the imperial ceremonial but in analogy of it, as we know from the pilgrimage liturgies in the early Christian Holy Land. The Acclamation of the cross during the Easter celebrations in the Anastasis complex in Jerusalem is an instance for which a good number of figured artefacts stand witness, amongst which the metal ampullae containing blessed oil. ${ }^{20}$ The monstrous little centaur in Bawit thus turns out to be a favorable

20 Krause 2000. For two examples of a couple of pilgrims, kneeling and extending high their right arm and flat hand towards the monumental cross set up in the Anastasis complex, on two ampullae in the Dumbarton Oaks collection, of which one cut into a cross-shaped amulet, see Ross 1962, $\mathrm{n}^{\circ} 65$ and $87 \mathrm{~A}$. 
and valorous companion to the saint, whom he salutes and approves of even though killing a human figure.

The viewer's key for understanding what role the artist has wanted the little centaur and the female hybrid that flies above him to play, is both in their freedom of movement, to which we shall return, and in this language of gestures. The flying female hybrid is a typical guardian figure, for equally turned both left and right, alert to wherever evil may come from. She has great powers in that she combines three natures: she has a lizard's (or snake's) tail, which is often used, in animal lore and iconography, as a sign of longevity if not eternity, because the little reptile's tail grows back if it is accidentally cut off; ${ }^{21}$ meantime, her wings show her agility to move through the air, or even her capacity of receiving heavenly orders. Her arms, turned right, have been painted as if opened and slightly stretched forward. This rendering brings to mind the typical byzantine in profile view of persons in the orans position. ${ }^{22}$ Prayer appears to be this female watcher's main action in the saint Sisinnios panel, a prayer which is as much one for intervention and required help, as a thanksgiving. ${ }^{23}$

An owl sits by the horse's head; its feathery 'ears' sticking up, it faces us with wide open eyes. ${ }^{24}$ The nocturnal raptor is a precious sentinel, for it sees in the dark. It acts as the night-watch on countless artefacts, and as such is a faithful companion to the helmeted tutelary goddess Athena-Minerva. ${ }^{25}$ In Bawit it stands on a strange saurian-like beast, with half-closed eyes, which can be understood as belonging to the group of 'evil ones' in the picture (inside the red oval frame in fig. 8). We will return to the other figures on the left of saint Sisinnios later. In this chapel of the Apa Apollo monastery, only the niches - on the east, north and west sides - the semi-circular lunettes, or tympana, and the four pendentives under the bare cupola were painted other than white. Three more horse-riding saints in the pendentives of the same chapel XVII could be identified as Phoibamôn, George and Victor; all are equally dynamic, with differently colored flying capes (as far as identifiable), ambling in a grassy and flowery landscape and looking towards us inside their very broad

21 A characteristic systematically reported in books on animals since Aristotle's Historia Animalium. 22 Such is, for instance, the Virgin Mary in the Deesis intercession prayer, where she is seen sideways on the left and John the Precursor facing her on the right, equally orans in profile, on the other side of the throne of Christ the Judge.

23 As her inscribed name translates "The daughter of Alabasandria", which is the name of the woman lying transpierced on the ground on the other side of the panel (see below), she may be begging for pity for her evil mother's sake.

24 Jean Clédat hesitated as to how to read this large shape -“...on voit un pou (?)” (Clédat 1904, 81). However, I shall not be the first to question this identification, especially as so many, recently discovered apotropaic artefacts have been found to use and figure this precious night watch, which is clearly identified as the 'noctua', chasing out the 'envious' evil, according to the accompanying inscriptions.

25 See the entry Athena-Minerva in LIMC 1984, II,1-2. The little owl accompanies the goddess quite often in Greek and Roman iconography, and systematically in post-Renaissance art. 
nimbi. ${ }^{26}$ The four large lunettes between them were filled with noble figures dressed in rich, ample clerical habits or festive attire, colorfully ornamented. Among them, and followed by a Baptism of Christ, stood an imperial-looking bust of the Ecclesia personified..$^{27}$ Every one of their wide haloes throws its light around them and on us. But most striking is their strict, typically apotropaic, en face attitude, their blessing right hand and, foremost, their immense eyes watching (over) us.

\subsection{Eye-Control}

In the context of Byzantine art there is nothing unexpected in this gallery of saintly protectors, but their function as such must be recalled. Many other sacred spaces, be they the pagan temples and tombs of the pharaohs, of the Romans, of the Parthians as in Dura Europos, or any medieval Christian church or chapel, are peopled with these rows and series of (benevolent) guardians, with observing eyes, in every niche and blind arch, on every pillar and wall and vault.

In the same Chapel XVII in Bawit's Saint-Apollo monastery the eastern apse carries such a tier with the Apostles tightly serried on both sides of the standing Virgin orans as in the traditional eastern iconography of Christ's Ascension. ${ }^{28}$ However, like a well-disciplined squad, all are looking straight ahead, at us, and not up towards the vast white nimbus of Christ's Ascension in the conch, riding on the flaming chariot of Ezechiel's vision, again, with countless little eyes all over the red wings of each of the four heavenly creatures. ${ }^{29}$

Warding eyes, indeed, are key figures of this whole protective system. A quite invasive visual control in fact. Today it finds countless analogies in the video-control and various security camera installations placed overhead at the entrances of banks,

26 Some, later monastic wall decorations also have a great number of not only standing but horse riding saints. Such is particularly the church narthex in the Saint-Paul's monastery where the saints James/Iakobos, Menas, Julius of Aqfâs, Abadir (with his sister Lady Irayd), Ischyrion with his camels, Victor of Assiut, Theodore Stratilates and George are all riding and of whom the two first and two last are trampling or transpiercing some monstrous foe: Van Moorsel 2002, 98-116. All of those mounted warriors, some riding side-saddle and thus almost completely facing us, have their haloed heads turned towards the viewer.

27 Clédat 1904, 73-100, 75 (fig. 48), pl. XLII-XLIX.

28 When the Apostles, standing en face and in line flank the enthroned Theotokos, as seen in Bawit or elsewhere, the relation with the haloed Christ in the upper level of the composition is far less evocative of the Ascension, the row of watchful eyes being just as impressive.

29 These eyes refer to the multiple ocelli in the peacock's tail feathers. These in Graeco-Roman mythology were said to be the hundred eyes of the guardian giant Argos, who was killed by Hermes, his eyes being subsequently set in Juno's peacock's tail. The link between the eye-studded feathers and the act of guarding is constant. 
ministries and public offices, including schools and shops and some cult buildings, in their battle against law-breakers of the most feared-thieving and life-taking-kind.

Just as we are made to react self-consciously to a video-camera aimed at us today, a number of devices, through time, were and still are aimed at the passer-by as the possible enemy. The rows of immense eyes noted as watching over us are plainly also just watching us, keeping us under control.

Funerary art reserves a generous space for 'eye control'. Some artefacts made for the living followed them to the grave for use by them in their afterlife and by their grieving and banqueting families and friends. In the Egyptian sphere, the udjat eye, the right-hand on $\mathrm{e}^{30}$, beautifully made-up, wards the sacred space of the dead and the gifts that accompany them. Its role is non-equivocally benevolent towards the inhabitants of the tomb whom they guard. Such is also the udjat eye talisman when made out of ceramic or some precious metal, towards the person carrying it, though it is suspicious of all others.

Of particular interest, though not reserved for a sacred space but met with in tombs, are the sophisticated Greek 'Augenschale', 'eye-cups', on which big pairs of eyes are painted on the outside. Between or flanking the two eyes, as well as inside these containers, other protectors are part of the painted surveillance system. A favorite is the Gorgona with her petrifying gaze; ${ }^{31}$ she or soldiers or warrior gods such as Athena or Ares or some other muscle-man all stand, ready to fight, the fight in this case being against poisoners.

30 Whatever the local language is, one finds that there is a semantic and lexical link between the 'right' hand or side and what is 'righteous'. The elect will dwell or sit on the right side of the sovereign, in court, at table, at the issue of the Last Judgment (see below), etc.: not on the 'sinister' left side.

31 The Gorgon Medusa's epic is all about eyes, charming, killing, warding. Her iconography is rare in sacred places other than funeral. She is shown strangled, with little wings, with half-closed eyes, and asks for a complex decipherment, which we have gone into elsewhere (Donceel-Voûte 2014, 364-366, and see entry Gorgo-Gorgones in LIMC 1988, pl. 163-207). The Etruscan figure of Death and transporter of souls, Charun, shares a number of iconographic characteristics with the early Medusa, such as large boar's teeth and excessively large eyes and eyebrows. These, together with his wrinkled and distorted features do not, however, make him an apotropaion, except in certain situations, as on sarcophagi: they simply serve as a statement, to establish the personification of Death (De Ruyt 1934). The precise situation of any motif in a large decorative programme is an essential component of any image's meaning, in a both visible and invisible syntax. The Gorgo's face, on the other hand, is mostly aggressive because of her petrifying gaze. Her beauty, which was at the cause of all her mishaps, was mostly overlooked before late antiquity. 


\subsection{Talismans and Amulets, Chrisms, Crosses, Swastikas, ...}

The two eyes combined with a cross set between them, on the modest though golden plaque found under Saint-Peter's in Rome is a typical amulet. Its precious metal carries such signs as are but details in the large decorative programs of sacred spaces, which they, however, furnish with an unambiguously magico-religious power that is part of their attractive aura. They are found integrated, only as details, in quantities of major figurative and ornamental compositions, as well as on minute artefacts, to be discreetly carried on the body.

One such age-old charm is the 'eagle-stone' particularly frequent in Egypt, though inherited from Mesopotamia. It presents itself as a brightly colored sphere, red, blue or green, and is set inside a golden yellow ring. It is also called the 'pregnant stone' because it is a geode with the cavity inside it containing little pieces of crystals or such mineral matter that rattle inside it when it is shaken, allowing the comparison with a pregnant womb. The other name for it - eagle-stone / 'aetites lithos' - stems from the typically Mesopotamian somewhat playful speculation on the sound of words, in this case the sumerogram 'erû', meaning 'to be pregnant', a word which sounds like the one meaning 'eagle'. The two remained linked in medical and animal-lore treatises and geodes were definitely integrated in the anguishing semantic field of child-bearing and birth. The motif - and the obstetrical use of geodes - travelled and attached itself to the Egyptian hieroglyph shên, a large knot, which is the attribute of the vulture-goddess Nekhbet, protector of maternity. ${ }^{32}$ She is mostly shown carrying the bright jewel-set ring in her claws; but in Late Antiquity we find the eagle stone/pregnant stone attached on a chain or torque-like necklace around the large bird's neck, and around that of female figures too. On countless early Coptic tomb stelae, the amulet-wearing bird stands en face, mostly with outstretched wings. Time passing, we find it associated here and there with a cross (see fig. 9). An ultimate key is given by eventual inscriptions accompanying the motif and giving the honored dead person's name: it seems always to be that of a woman. The amulet is thus specifically feminine and concerned with maternity and all-important family and fertility matters.

Of the other, better-known protective signs such as the cross or the chrismon combining the chi and rhô of Christ's name, be it with an X-cross or a standing one we will observe the very important semantic and also formal analogy between the cross or chrism and a number of knotted motifs such as the Solomon's knot. This is evidenced by a great number and variety of artefacts. This relation will allow a qualification as protective of them all, and not only of the cross, whose function as such is well-known.

32 Donceel-Voûte 1983. 


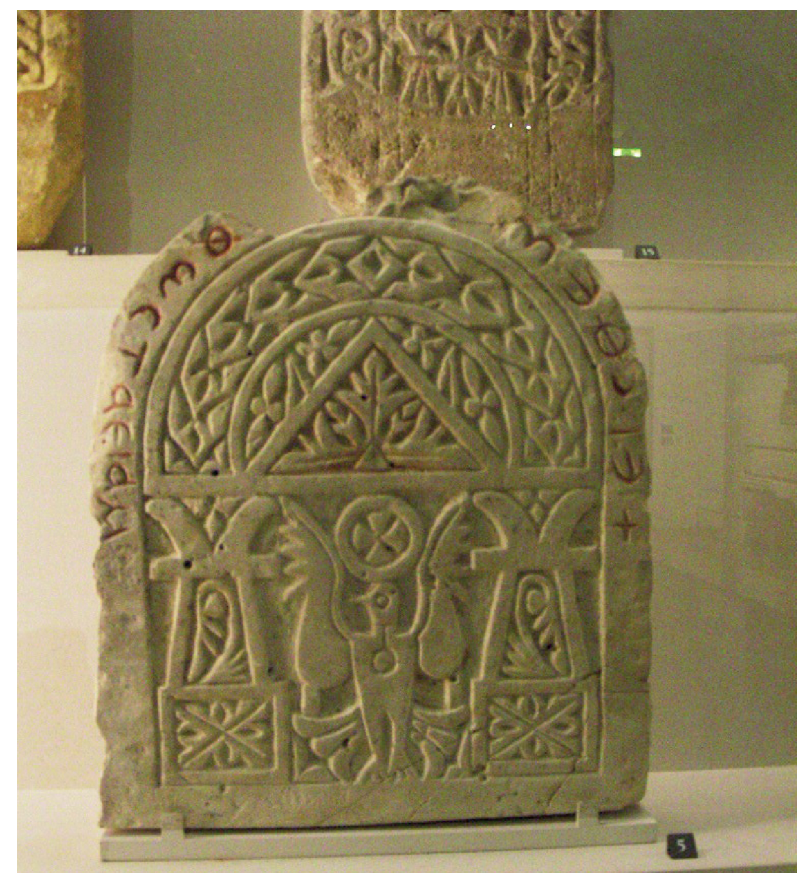

Fig. 9: Egyptian stela with cross and eagle wearing an eagle stone / pregnant stone, Louvre Museum. (๔) Donceel 2014).

A clear proof of this analogy is that of the long $4^{\text {th }}$ century mosaic pavement found in Zahrani on the southern Lebanese coast. ${ }^{33}$ The row of motifs along the middle axis of the composition alternates - a cross, - a Solomon's knot (two rings entwined crosswise), - a chrismon (here of the early 'Constantinian' monogram type with standing 'P' and cross), - a Solomon's knot, - a Greek cross with four little identical crosses between the arms, in each quadrant, - and another Solomon's knot.

Another famous occurrence is known since the 'thirties' of the $20^{\text {th }}$ century excavations of the early levels of the Nativity church in Bethlehem. The late $4^{\text {th }}$ - early $5^{\text {th }}$ century mosaic pavement has a small panel on both sides of the primitive stairs leading down to the closed-off rock cave, where the manger and the golden star in the eastern niche are the keynotes. ${ }^{34}$ The panel on the left is from where the hordes of pilgrims descended, the left side being the entrance side. ${ }^{35}$ Its composition com-

33 Donceel-Voûte 1988, 437-439 and Donceel-Voûte 2014, fig. 9.

34 Kitzinger 1970, 645-649 is clear about the relation with the primitive descending flight of stairs. He proposed to explain the iconographic preeminence of the left-hand panel over the right one by a possible turn changing the axis of the stairs.

35 People always moved on the left side of the roads, which we know in particular from Roman times. It is only since Napoleon the Ist, who made his wheel-driven carriages drive on the right side of his marching soldiers, that carriages but also people in dense traffic got used to walking on the 


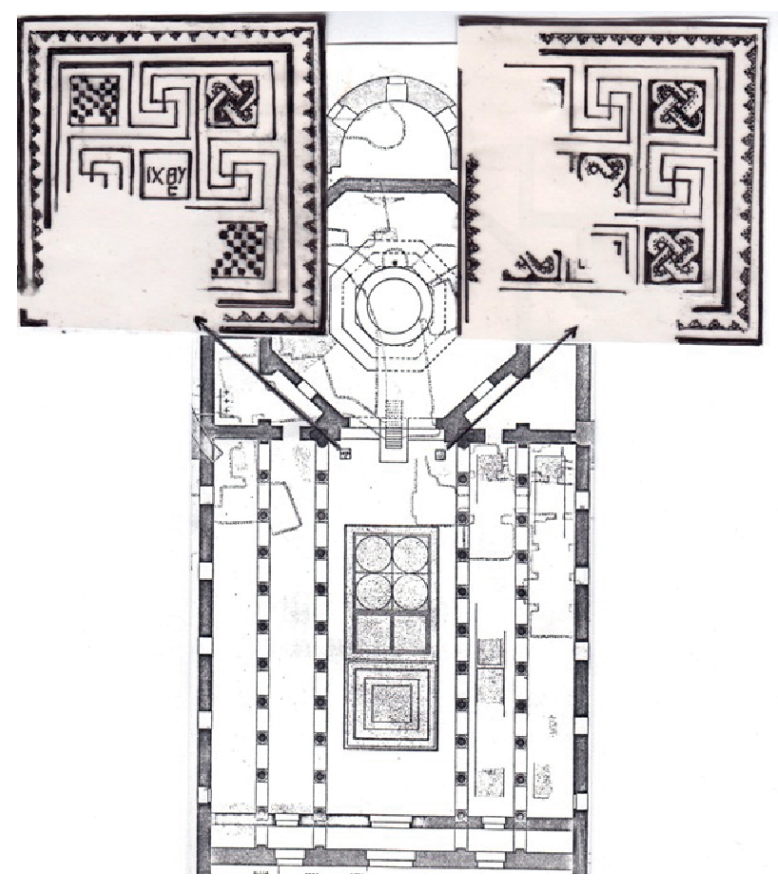

Fig. 10: Bethlehem, the panels left / north and right / south of the stairs down to the Nativity grotto. (C Donceel-Voûte, plan Revue Biblique, 1936).

bines an endless swastika meander with four Solomon's knots (each knot inextricable) and with a central inscription of five letters: IXOYC. Not only is the IChThYS, i.e. the 'fish', as all motifs linked to see-faring, such as the boat, the fisherman or the

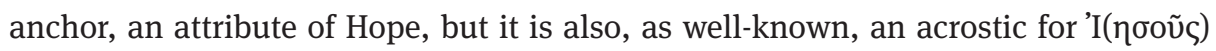

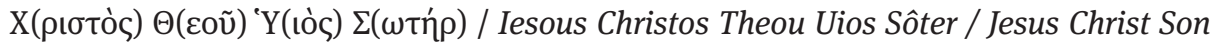
of God Saviour, a soteriological acclamation, full of trustful expectation; it is an excellent choice for decorating the threshold of the miraculous birth site (fig. 10). Visitors coming up and out of the Bethlehem cave, were met on the south side of the stairway by another small panel, this one decorated with only the swastika meander and five Solomon's knots, set in the corners and the middle. This lay-out is evidence for a strong semantic link between the cross-like Solomon's knot and the name of Christ, savior and figure of Hope, in the middle of the twin panel on the North; they are here enhanced by the dynamic movement of the running swastikas which, like many wheel-like signs, are ancient highly dynamic solar motifs.

right. No ancient, medieval or modern building until the early $19^{\text {th }}$ century should be visited without remembering these essential 'directions for use'. 
Many other artefacts will use other combinations of some or all of these more or less non-figurative ornaments. Isolated, but more often combined, each of them is a strong signal, enjoying a universal and timeless career, as the following category of signs confirms.

\section{Traps, Nooses and Deviations}

These motifs are not apotropaia. They function quite specifically in their fight against evil. Solomon's knots as all other interlaced and interlooped motifs do not ward off: they keep trapped. We may call them a 'Devil's trap'. The same goes for the 'pentalpha', a five-pointed star drawn without lifting the pen, though it must carefully pass under-and-over alternative straps to allow them to be pulled tight. The six-pointed star, drawn by two equally interlaced triangles, belongs to the same semantic field.

For all these motifs the relation with a noose is inevitable, all the more as the

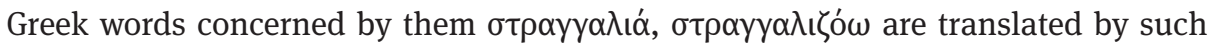
English terms as "lace”, “cord”, “strap”, “chain”, "rope”, “twist”, "snare”, "knot”, which establishes an etymological link with the action that interests us here, that of strangling.

These closed and endless knots are thus found to serve as security locks or traps against devious, malicious minds, thus leading them off.

A recently published series of examples are the colorful motifs at the foot of the page, at the end of the chapter, or at the lower edge of the frame of some New Testament scene in the magnificent Syriac Dioscoros Theodoros lectionary ${ }^{36}$ (fig. 11). The artist secured the pages with multiple sophisticated and dynamic itineraries moving on and back again and over and under as if to get the intruder lost, while the net effect resulting from the braided interlace may well be intended to snare malevolent powers. That these devices serve in a spiritual warfare is evidenced absolutely clearly on certain pages of the same manuscript where the inscriptions (in Syriac) that surround one carpet-like cross inside an interlace border reads: "Signal of peace and symbol of victory". Around another cross, covered and framed by abundant and intricate interlace compositions, the inscription reads even more aggressively, about transpiercing one's enemies and trampling one's foes", thus setting the scene for a bloody battle ${ }^{37}$ (fig. 12).

36 Kaplan 2013. Around the Baptism of Christ miniature, the wide interlace border interloopes with a circular set of red and green knots that works as a lock in the lay-out of the page; it does so equally on the facing text page (Kaplan 2013, 130 (fig. 99), and 129 for the facing manuscript page).

37 Kaplan 2013, 56-61. For the acts of transpiercing and trampling - the latin calcatio - in figured art, see infra §IV,1. 

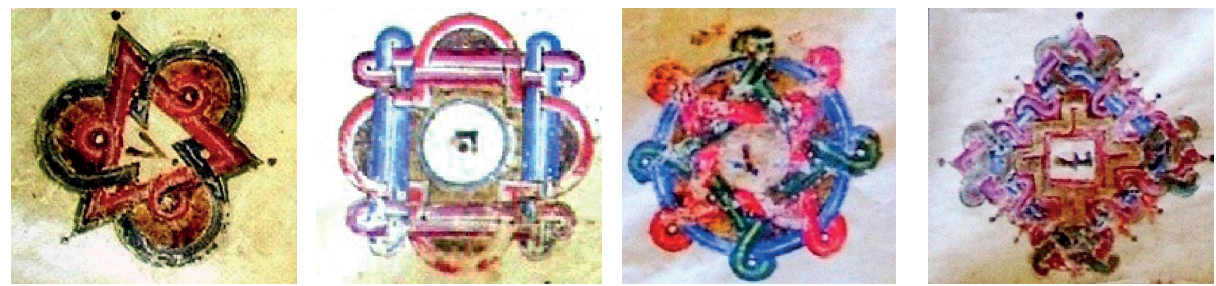

Fig. 11: Dioscoros Theodoros Lectionary, knots opening quire 3 and closing quires 4, 7 and 8. (Kaplan 2013, fig. 72, 75, 79, 81).

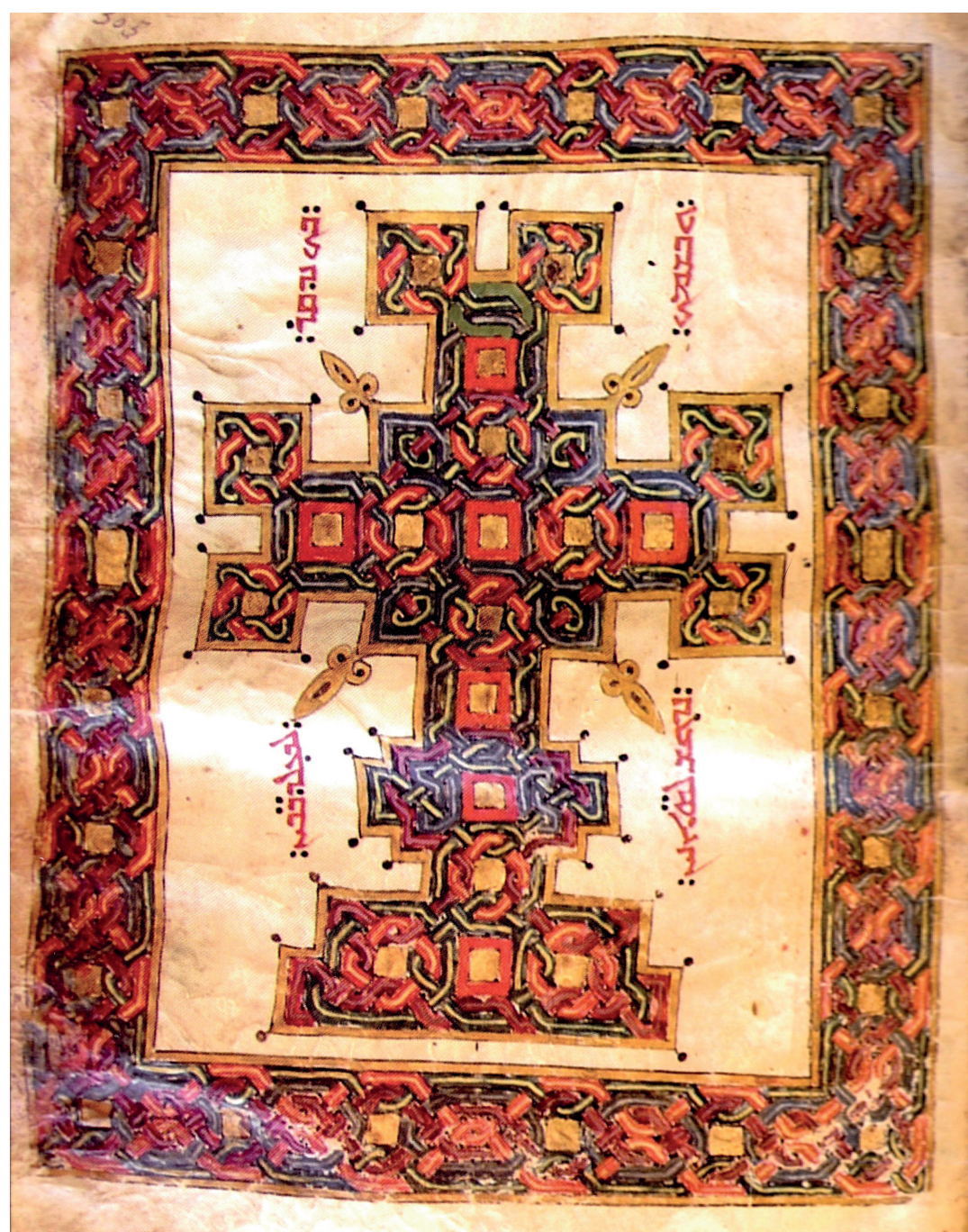

Fig. 12: Interlace cross in interlace border with Syriac inscription "By You we shall transpierce our enemies ...". (Kaplan 2013, fig. 13). 
An analogous commentary can be given on 'Celtic' ornament, on monumental Irish or Breton crosses, or on the famous Armenian khatchkars. A number of these elaborate cross-stones have leafy twigs branching off their foot that no doubt identify the sign positively, as a tree-of-life, while its defensive powers are in the cross shape itself, in its tricky interlace and in its frequent, though secondary, shield motif, already commented upon (fig. 7).

Reliefs with these knotted motifs are also cut into the masonry of buildings, of which the most spectacular are in churches and monastery walls in Armenia and Georgia. In Armenia they often look like a monolithic khatchkar set high or low into the wall. Here as in Georgia and elsewhere they evidently serve to preserve and protect the whole building, inside and outside, together with the whole neighborhood. In non-Byzantine Europe this would be the job of figures of massive saints and angels, sculpted in the round or in high relief, standing in or on top of the façades with a host of crosses. It is in India and in the whole far eastern world that the most colorful masses of deities of human, animal or hybrid nature are heaped on top of the monuments offering their protection and vigilance.

Complex apotropaic assemblages that combine images from the different categories defined above are seen to cover the total surface of eastern Christian church façades as well as their roofs and doors. They use not only a) crosses of all sizes and ornaments, b) massive inextricable knots, c) interlace in endless bands or in frames, but also d) angels and e) powerful animals - mostly lions, eagles and dragons isolated or victorious. In certain buildings, such as inside the Armenian Geghard complex, or on the outside walls of the Georgian Ananuri church, pairs of lions chained to an interlace knot are cut into the magnificent polychrome ashlar masonry (fig. 13). With the help of a pair of entwined dragons, chains, crosses and knots of all sizes and ornamentation, they will defend the monument as long as it stands and more.

All these iconographic devices anticipate the coming of evil. They prepare a defense against the enemy's intrusion. Unwelcoming, most of them imply that access can be denied. 


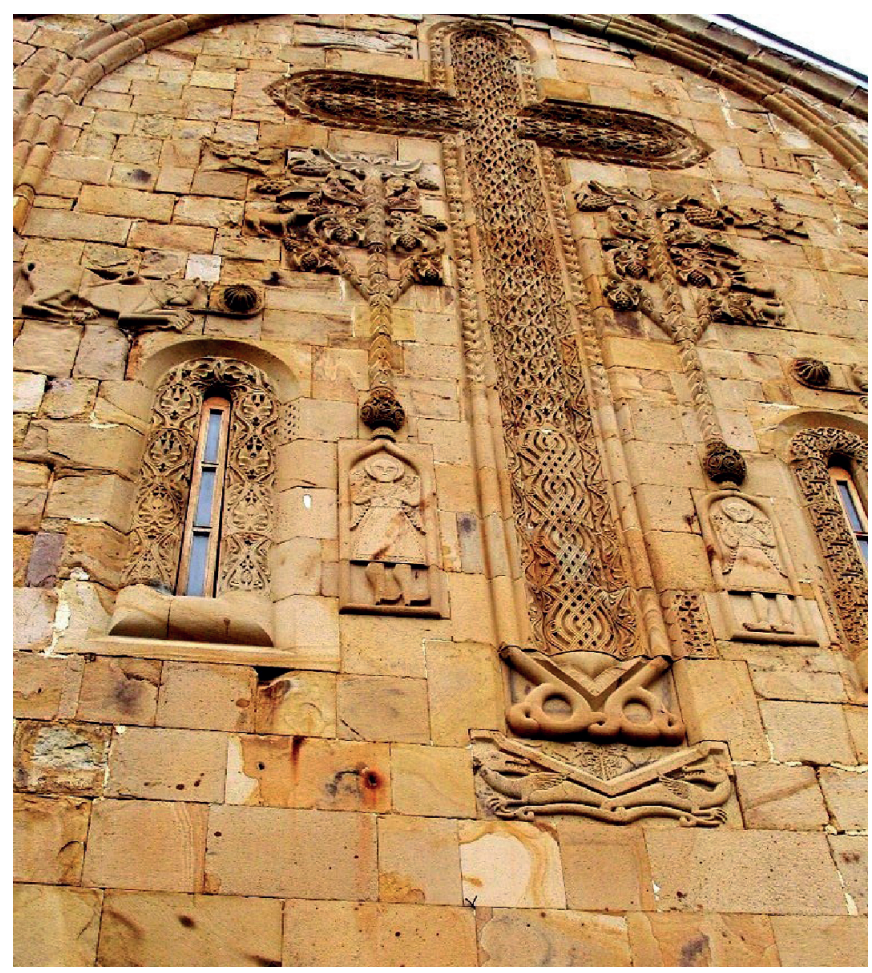

Fig. 13: Façade of Ananuri cathedral, Georgia. (๔ Donceel 2015).

\section{Checkpoints, Passwords and Conditional Entry}

To these and other devices already noted must be added inscribed artefacts, epigraphs containing questions that induce an act of conscience in reference to moral values. As these are also met with on thresholds they are a checkpoint to stop the 'enemy outside' from becoming the, most unwanted, 'enemy inside'. These written enquiries, these mute exchanges 38 set the scene for a moral drama at the entrance of sacred spaces. While the vast majority of 'religious' inscriptions through time and space are addressed to a god, these messages are addressed to the people. In that, they function like the iconographies previously observed.

38 Familiar in domestic and non-sacred spaces, all over Graeco-Roman Asia Minor and the Near East, Syria especially, are such Greek inscriptions as "Alype khaire" = "welcome if you bring no sorrow", or, less frequently and mostly accompanied by a guarding figure "Kai su" = "And you? [=And what are your intentions?]", which are quite comparable though in a lighter mood; see Donceel-Voûte 2014, 369-377. 
Some of the clearest written messages I have been able to observe in such a situation quote or paraphrase the Scriptures. This fact, no doubt, seeks to establish that they are lawful requirements, especially concerning sacred space, although we find them to have served elsewhere, namely at the entrance of domestic spaces. It may be that highly traditional iconographies, such as those just observed, are invested with an analogous respectability. The advantage of the first over the latter, however, is that the one sole language of an inscription is not as universally understood as is the iconic language.

Conditional access is offered to the visitor by the, very frequent, quotation of Psalm 117/118, 20: “Only the righteous - Dikaioi cshall enter these gates”. It means that all those with a dubious morality are excluded - i.e. should exclude themselves from entering those particular gates. This is 'said', for example, by the engraved tabula ansata over the main gate in the Sinai Burning Bush monastery, or by a panel set in the pavement of the narthex or the threshold of a church. ${ }^{39}$

Rather than a question about the entering person's state of mind it is a discreet order, the reminder of a disciplinary ruling that is directly spoken by the building and its decoration, these representing the Church and, beyond, God.

Another psalm serves this purpose on the side aisle threshold mosaic of the southern Lebanese church of Qabr Hiram:40 "+ Eirenè hè eisodon sou ( $h$ )ô blepon”, "Peace be on your entry, you who see"/ "Let peace be in your coming, O seer". This sentence is an adaptation from Septuagint Samuel I,16,4, "Seer, do you come in peace?" or is it "do you come for peace?". The seer in the Bible is the great (blind) prophet Samuel and it is to him that the question was addressed. Here the seer is the visitor, who, passing the threshold of the church reads the inscription addressed to her/him by the 'talking artefact'. Now, the viewer has to observe two things: the mosaic as an object to be read, and he/she herself/himself in his/her most intimate conscience. Considering similar phrases and the images previously observed, this gate inscription functions as an invitation to that brief act of conscience, notwithstanding the prophylactic undertone. ${ }^{41}$

39 Examples in the narthex of an early Christian church in the northern Negev (site currently of a kibbutz Magen), between the aisles as found in Beth Shean/Tell Basul, or by a door as under the Carmelite convent in Jerusalem, or in the Bethlehem Nativity church complex, to give but a few, near eastern, examples.

40 The entire, highly decorative pavement has recently been newly exhibited on a floor (instead of the walls, as previously) of the Louvre Museum; this inscription however has not found its place back on the edge of the (originally north) outside wall in the plan, which deprives the monument-and the visitors-of one of its more subtle messages (Donceel-Voûte 1988, pl. h.t.17 and p. 414; Donceel-Voûte 2014, fig. 25).

41 Another occurrence of this same phrase in the same place is known from the ancient Syrian capital Antioch, but on the threshold of what was identified as a room in a private dwelling. This 'Mosaic of the Biblical Inscription' in Antioch, as it figures in catalogues, within ornament datable to the late $5^{\text {th }}$ 
Inscriptions with "Saintliness is due to your dwelling", from Psalm 93,5 (Vulgata 92,5), were discovered inside the church space, at the entrance of the choir and at the foot of the altar, as if checking the clergy, but also in the narthex, examining all (Greek-reading) visitors. ${ }^{42}$ In other words, they were used for checking the entrance into the entire sacred space, and not only those parts that were reserved for the clergy, from whom one might most expect 'holiness' and not only 'peace' as of the lay faithful. ${ }^{43}$ Again, it is a reminder that addresses the morality of the reader.

Much more frequent in epigraphs linked to the entrance of private as well as public buildings, and less ambiguous, is the quotation from Psalm 120,8 "May the Lord protect you when you enter here as when you leave". Sometimes the quotation is completed, ending with "now and for eternity" 44 which establishes a link with secure longevity, one of the blessings one expects to experience in sacred space, as we shall note again. The shortest possible formula is the variant "Peace (be) on your coming and your going”. The inclusion of the wish for a peaceful departure has a definitely more generous overtone which indicates a shift from an appeal to self-control, before daring to enter, to a propitiation. No entrance has been found to carry a permanently aggressive formula, which seems logical: ${ }^{45}$ daily life and liturgies would not allow such an incivility.

Through time, in the Near East, where most of the above examples are found, it appears that the majority of these verses echo the polite goodwill formulae said by the visitor or by the host/clergy in profane or sacred contexts. ${ }^{46}$ They are an expression of inspired hospitality.

century, certainly functions both as a question to one's conscience, and a measure of security on the owner's side.

42 For instance: at the entrance of the choir closing off the $6^{\text {th }}$ century nave in Qabr Hiram (southern Lebanon) (Donceel-Voûte 1988, pl. h.t. 17 and fig. 484), - as at the foot of a massive altar surrounded by further mosaics of interloped knots and stars in the northern Negev (a site given the name Ber Shema, identified as ancient "Hellad of the Gerrarens" as mentioned in the baptistery pavement) (Qadmoniot 1992, 37 (figure)) and-in the north-eastern part of the narthex of an early Christian church in Ascalon/ Barnea, further N. and on the Mediterranean coast (Israel Exploration Journal 1965, 125-126).

43 Various liturgical texts inform us that the lesser clergy was mostly active in the aisles and nave and in the low choir precinct preceding the podium of the altar itself, around and in front of which only the higher clergy - deacons, deaconesses, priests, bishops...- was allowed (Donceel-Voûte 1988, 502-525). Thus 'holiness' appears to be considered a possible goal for all members of the community of the faithful and not only for the clergy around the altar.

44 "For now and all centuries" is added to this formula in the narthex of the Elias, Mary and Soreg church in Gerasa / Jerash.

45 These formulae are conditional or wishful. They do not have the aggressively confident overtone of Greek Psalm 90 (Vulg.91), absent from thresholds but so frequent on corporal mobile amulets (see in this volume Thomas Kraus, "Archäologische Artefakte mit griechischem Psalm 90 in apotropäischer Funktion”, 121-138).

46 Donceel-Voûte 1988, 466. 
Such more or less prophylactic formulae are, however, far from the overwhelmingly welcoming, blessing Christ over the door in the most famous entrance programs of the full Middle Ages in the Byzantine sphere, who proclaims "Peace be with you. I am the life and the light of the world". ${ }^{47}$ Truly, the gold-leaf and glass mosaics of the background hold and mirror an unfathomable light in all directions, creating an immaterial dimension of a sacred and blissful nature. Everyone is welcome, each one responsible in his/her soul and conscience, receiving a protection proportionate to each one's purity, but none trapped or captive, excluded or sent away to 'get lost'.

The artists who followed the quest for perfection and harmony worthy of such sacred places as those mentioned, encouraged and represented the blessings most asked for, which are also those one most fears to be bereft of: ambient peace and long-lasting order and harmony lost by war and violence; light, bright hope and joy lost to darkness and its forces of despair; permanent beauty lost to the menace and ugliness of sudden death and destruction; as well as powerful, active, capable and lasting protection ${ }^{48}$, unsettled by capricious impermanence and the insecurity of disorder and chaos.

The malicious author of those deeds, commonly identified as 'the devil', is conceived as jealous, envious of all those blessings, and intent, through all the misdeeds engendered by hate, envy and treason, on depriving its victims of the people and belongings they most cherish, leaving them in powerless poverty and helpless vulnerability. The nature of dreaded evil is mainly loss. This void is rarely figured..$^{49}$ Art is more apt to picture the author of that absence: this is done mainly by ways of a personification, animal, human or hybrid, as we shall see.

47 Famous Eastern Christian examples are the tympanum over the door to the nave in the Constantinopolitan Haghia Sophia, or in the catholicon of Hosios Lukas in Phocis, where the newcomer is greeted by the intercession prayer of the Deesis between guardian angels before receiving the unconditional divine welcome (Donceel-Voûte 2014, 375-377). The masterpieces of Romanesque and gothic tympanum sculptures, on the other hand, carry more equivocal messages such as that of the Last Judgment, which combine the vision of future bliss with a warning, and are thus more in the spirit of the threshold inscriptions just commented upon.

48 Each religion will have its own repertoire of benefactors, human and superhuman, to be active in their places of worship. We also know of such emperors as Nero, Hadrian, Antoninus Pius or Marcus Aurelius, who combined scores of helpful, hope-inspiring, life-giving deities and god(desse)s, philosophers and wise men to conjure contrary forces. This 'safety in numbers' strategy translates in various shapes in the most distant civilizations. We may recall the medieval and late Byzantine calendar icons, with their rows of female and male saints and scenes of the events commemorated in the great annual liturgical feasts, each month bringing its wealth of renewed security and potent patronage.

49 A small number of representations of Hell offer spaces of empty darkness or grey nothingness, as on the south wall of the Christ-Saviour-in-Chora church (Kariye Djami) in Constantinople (see below) (fig. 17). 


\section{Evil Visible: Scenes of War}

As soon as the evil enemy ${ }^{50}$ is visible and clearly perceptible, the iconographic repertoire in charge of managing defense is abandoned for one of open war and battle. The focus is on stabbing, piercing, blinding, lancing, trampling, strangling, chaining, fettering and more.

Why? Because 're-presenting' Evil means that it is 'made present', that we are brought face to face with it. Indeed, the mere presentation of it on an artefact would allow it to become freely malevolent, wrong-doing, deadly, in and outside that artefact. This threat is ontologically inherent to artistic creation as stated in our first sentences.

However, further observations evidence the nullification of that consequence in that Evil is only represented as attacked, or rather already vanquished and/or shut up, not leaving it a chance to cause havoc.

We are here at the heart of a crucial 'Power of the Image' statement: presence is created through the act of figuring, by mere re-presentation.

This iconography, with evil visible, is therefore not just one of war: it is one of triumph. It needs to be such for our safety. The clue to these scenes of victory is clearly that the vanquished one is to be identified as the 'bad one', who got, or will be seen to get the punishment he was entitled to get. One may formulate the identification operation as follows: "the victim is the evil one", the loser deserved its downfall. This understanding, which may be appreciated as a major iconographical clue, applies to artefacts of profane and religious inspiration.

A particularly edifying case in point is that of the tempera wall painting with saint Sisinnios which has already been singled out for its rich iconographical vocabulary (fig. 8). Instantly, the image establishes this rider as an obviously admirable figure, and we cannot but agree with his actions. Around him, we have, on the right, hybrid figures flying, standing and gesturing freely which implies that they are peaceful and benevolent figures. On the left side in the picture, the different figures, animal and human, i.e. the half-naked lying woman, the Eye and the saurian, are all attacked, transpierced, caught and dying. They are thus to be understood as bad and malevolent, or rather, as having been thus, because the saintly warrior and various weapons and animals have defeated them already, in the picture. The woman lying on her back on the floor, arms flung out in protest, is here named "Alabasandria". She is also known from various texts and artefacts as Gello or Gylou or Lilith, or Morra, or also as Anabardalaia, Apletou or Abyzou or Byzou, or Chamodrakaina, or Petasia or Pelagia

50 The identification of 'evil' with 'enemy' may seem excessive but it is of consequence in the field of iconology where the one and the other appear to be treated similarly so as to be unequivocally read. As a consequence, the iconographically identifiable Evil One may serve as a 'type', a generic 'model' for the particular 'enemy' which the user of the image intends to pinpoint (see infra). 
or Bordona ${ }^{51}$ or just Wickedness, ponerî, ho ponerros ${ }^{52}$. She is well known as a particularly active evil demon in situations of pregnancy and childbirth, robbing, maiming, killing, and bringing sickness to both mother and child. She could well be the unspoken terror fought by the eagle-stone amulets that we have previously observed. She certainly is powerful as she wears jewels and bracelets in the Bawit scene which show wealth and therefore power, as we have already noted. A small monogrammatic chrismon precedes her written name, as if to be sure to exorcise the power of its wearer. ${ }^{53}$

The 'war against and triumph over Evil' semantic field has a relatively poor though contrasted iconographic vocabulary but the schemes available belong to long traditions and remain vivacious through time. A particular category of variations on the theme of 'the victim (the defeated one) is the evil one and the winner is the good one' is to be found in French Romanesque capitals, that have been subjected to quantities of unproven readings.

The observation of but a small number of them will suffice. Several of the creatures in the capitals of Fontevrault, Champigny, Lurcy-Lévis, Civaux and, best-known, Chauvigny are man-eating hybrids. The man-eating beasts, doglike, wolflike - some ostentatiously female which signifies beneficial fertility -, several with one head for two bodies - which allows them to sit at the corners of the capitals and watch both ways -, some griffin-like with a reptile's body and more physical variants, but all mostly looking quite jovial, are to be understood as analogous to the above-mentioned hybrid keepers, ready to jump on culprits. The beasts' gentle eyes and smiles, though their teeth are visible, contrast with the evil characteristics of their victims sticking out their tongue, clasping their hands, baring their long teeth - (fig.14), thus allowing, or rather, imposing the following interpretation: it is never the evil one who is pictured victorious, however 'monstrous' the winner. Here again, the evil one (monstrous or not) will not be allowed to run free inside the common sacred space of these churches. The sculptors though giving life to both the 'good ones' and 'bad ones' swiftly deal with the latter: they just have them gobbled up. For everyone's safety, the rule is 'Only (the) good (one) can be (shown) victorious', the corollary being, as already stated in other words, that when evil is visible it is vanquished.

For the many medieval sculptures and paintings, in the West and East, which feature various victims of the most diverse or composite creatures, successive attempts to distinguish every individual figure and action have failed. ${ }^{54}$ They may well find a consensus in this reading.

51 Greenfield 1989; West 1991.

52 As on a $4^{\text {th }}-5^{\text {th }}$ century bronze circular amulet in the Dumbarton Oaks collection (Ross 1962, 60-61, pl. XXXVIII).

53 She is, however, not the only one to be preceded by such a little sign, which is either a cross, a psi shaped form or, as here, a proper chi- rho chrismon.

54 The difficulties encountered show up for example in the little, well-illustrated book by Ingeborg Tetzlaff, Romanische Kapitelle in Frankreich. Löwe und Schlange, Sirene und Engel, Köln, DuMontSchauberg Kunsttaschenbücher, 1976, where the text and captions for fig. 45-49, 80, 88, 90, 93, of 


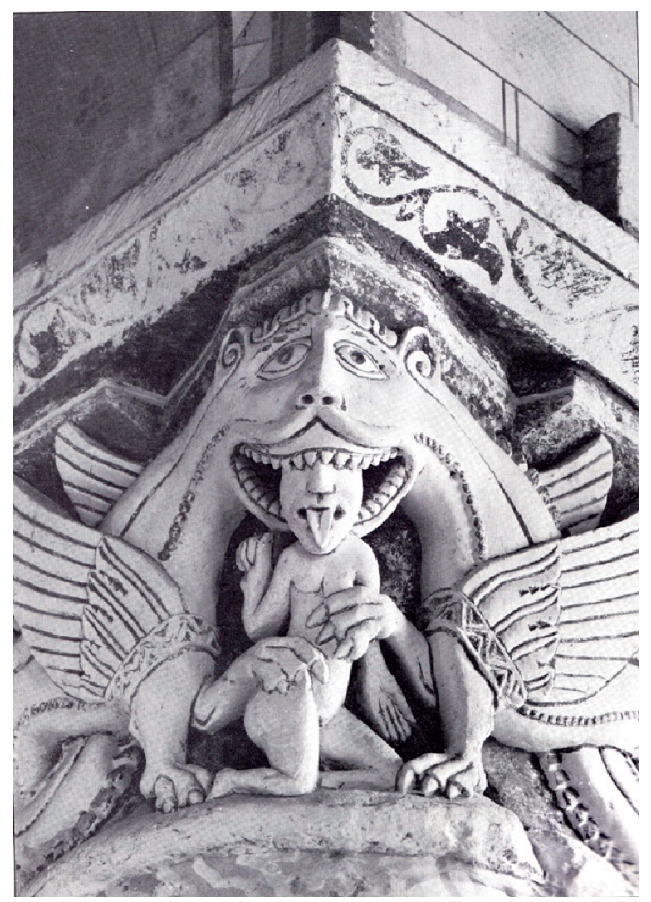

Fig. 14: Hybrid watcher eating up a figure thus understood as evil, Chauvigny church. (@ Donceel 1973).

\subsection{Calcatio $=$ Treading on the Evil One}

Treading underfoot means to thoroughly dishonor the enemy. This great classic of the iconography of victory has been given a Latin name, ${ }^{55}$ though the scene was set for such a grounding of one's opponent long before the word was used. It is a particular favourite in relation to personal 'enemies'. The defeated figures, who have been brought to the floor and trodden upon, form a horizontal mass in contrast with the verticality of the victor, a heroic figure. This is the key that makes the message unequivocal: those that have been knocked down must be considered evil.

Most ancient and most frequent through the history of the arts is the overtly triumphal scene with the conqueror frankly standing on the defeated one(s) who are lying dead under their feet. These victims can be more or less monstrous in shape, others being purely animal or human. In the last case the particular clothes, head-

which several with naked 'victims' as in contemporary Last Judgment scenes, give no justified explanations.

55 Dunbabin 1991. 
dress and other physical characteristics are clues to precise identifications by their contemporaries, and by historians. ${ }^{56}$

On the well-known and particularly dramatic Naram-Sîn stela (Louvre Museum), the victorious king, shown extremely tall according to the 'hierarchic perspective' (read: the tallest one is the most important one hierarchically speaking), tramples a heap of dead bodies while reaching up from a mountain peak to the skies and his planetary gods. ${ }^{57} \mathrm{He}$ is just stepping out of the battle scene and stands in a state of triumph, and not in the chaos of a heated combat. This allows the victor to be poised in a noble stance, erect and dignified. Evidently this iconography is a manifesto and not a narration.

The saint George in two of the most remarkable repoussé silver and silver-gilt icons from Georgia is sitting on his tall horse while keeping his enemy's head under his foot in the stirrups. This gives him an exceptional majesty. He lets his horse help him with the job of trampling the defeated enemy, who is figured twice in the Mestia museum icon: once as a Roman soldier and again as a gigantic serpent (fig. 15). The soldier is identified as the emperor Diocletian, the one who ordered George's killing. However, late $3^{\text {rd }}$ century's Diocletian has little importance for the post-medieval artist and the public this work of art concerns: the iconological clue is that Diocletian here lives on as a prototype, a type of the cruel prince, of the savage enemy, of the maleficent infidel. He is the impious sovereign to be gotten rid of thanks to the intervention of that other type: that of the great, ever-active warrior saint.

Equally belonging to the Eastern Christian sphere, the Dioscoros Theodoros Lectionary, already commented upon, offers a perfectly analogous message. However, the language and lay-out are of another nature. Here, the violence of war is in writing: "By You we shall transpierce our enemies and by Your name we shall trample our foes" (fig. 11). The Syriac inscription is read from top to bottom, first right then left, and surrounds the high-standing, intricately plaited and knotted cross; it implies an energetic transfer of the splendidly colored Christian emblem from the manuscript page to the hand of the reader, turning the image into a major apotropaion and weapon against its and other enemies to come.

56 See below for the changing apparel of a victim of saint George as the mounted warrior type hero (§IV, 2).

57 Parrot 1960, 176-177 (fig. 212-213). 


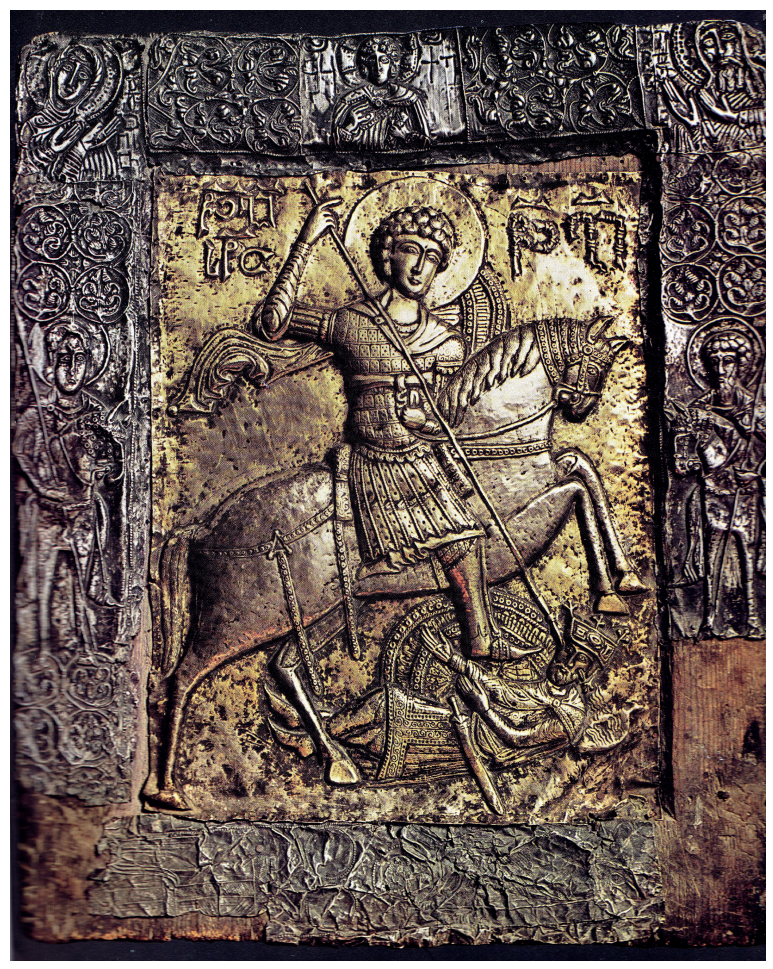

Fig. 15: Saint George victorious of his foes, silver gilt icon, Mestia Museum. (Alpago-Novello/ Beridze/Lafontaine-Dosogne 1980, ill.58).

\subsection{Battling Heroes; the Mounted Warrior and His Particular Enemies}

Most of the mounted warrior figures such as saint Sisinnios and saint George convey the energy of the on-going battle. They dominate the scene from the back of their muscular horse, with capes, horse's tail and mane flying. These movements can be read as meaning that they have just emerged from the race and battle and that they come to a halt. They are probably more of a statement of the figure's permanent dynamism, confirmed over and again at each observation of the image as the focus of prayers, be they of request or of gratitude.

The view in profile of the mounted warrior, especially towards the right, adds to the impression of energy produced: he is in movement, getting on with it. Before the next remark, concerning Egyptian and Caucasian works of art, it needs to be remembered that horsemen dominated in medieval warfare in these areas, the preeminence 
of the cavalry being due to its mobility, its superb horsemanship and the skilled management of its individual arms. ${ }^{58}$

In the frame of the silver gilt icon in the Mestia Museum treasure, two more haloed horsemen multiply the main saint's energetic message. They stand in an unusual en face view, left and right of saint George, who seems to carry a horseman's javelin rather than the more usual lance with a cross. They all turn their heads slightly in different directions, though one cannot say if it is to survey those angles or to watch saint George prancing on the middle axis. They form a little cavalry troop, as did Saint Sisinnios and the three other horsemen in chapel XVII in the Apa Apollo monastery. ${ }^{59}$

This and other medieval saint George icons with Georgian inscriptions offer remarkable examples of 'updated' iconographies of the evil one. In this case, the (to be) defeated enemy is Diocletian, the end $3^{\text {rd }}$-beginning of the $4^{\text {th }}$ century Roman emperor who is (to be) killed in his turn by the martyr he condemned. ${ }^{60}$ The way the emperor is dressed is rarely archaeologically correct. He does wear an ornate, quite convincing, late Roman military uniform on the silver-gilt Mestia museum icon, to which its sculptor has added a 'western' medieval, gemmed and pinnacled crown. The emperor in the Sakao icon is dressed in pointed slipper-like boots and clinging leather leggings up to the knees under a tight, long-sleeved tunic, with an all-over motif of roundels which may be read as silk or as ring-mail; his hair and pointed beard are carved in sleek strands, akin to post-Sassanian Persian types. ${ }^{61}$ This evokes the endless problematic geo-political relations between the Caucasus (Christian) inhabitants and their neighbors and/or invaders. On the other hand, the Labetchina silver icon, now to be seen in the Tbilissi National Museum, has dressed the outdone enemy as an Arab chief. ${ }^{62}$ His beard and hair are curled, a loose spherical turban on his head. He is armed with a small axe, and wears a short coat of scalloped mail, over the cuirass, knee-length leggings and short boots which are, in fact, identical to those carried by saint George, here and on the previous two icons described. ${ }^{63}$

These iconographic tactics of wished-for victory adapt and modernize age-old canvases by only slight alterations.

58 Parry 1977.

59 See end of §I.4 above.

60 Diocletian had George tortured and finally beheaded. The present iconography with Saint George riding high not only portrays a wished-for event; it works as some sort of a revenge, the executed martyr having become the executor.

61 Alpago-Novello/Beridze/Lafontaine-Dosogne 1980, fig. 59-60.

62 Alpago-Novello/Beridze/Lafontaine-Dosogne 1980, fig. 61.

63 Many narrative scenes of martyrdom, especially in easel paintings from the Renaissance times onwards, present an updating of the persecutors, giving them the costume, hair and beard style and even features of the then condemnable authority in the eyes of the artist's patron. 


\subsection{The Evil Eye Attacked and Defeated, Pierced, Blinded, Stabbed, Poisoned, Bitten, Picked at}

The viewer of the two previous iconographic types can make out that 'the evil one' is the one being trodden on and mastered.

The same viewer can similarly identify which is the malevolent Evil Eye and which is the benevolent watching eye - such as the udjat eye already commented upon only and simply by the fact that the 'evil' one is represented already vanquished. The creating artist must and will not let the represented Evil commit its crimes freely. We are not being brought face to face with it unarmed. ${ }^{64}$

This Evil Eye, although there is but one, even in its earliest known pictures, is extremely potent. One of the Khafadjeh (Iraq) clay slabs ${ }^{65}$ shows the full-length oneeyed, powerful (because its head is set in a wide flaming halo of disheveled beard and hair) demon being strangled and pierced by the dagger of the long-mantled, bow-carrying divinity. The eye is untouched but the chest wound is fatal and the grabbing hands of the envious Evil One are firmly paralyzed on its back. This relief is already as strongly dramatic as the so much later heirs to this iconography, where the eye is isolated, without a further body, as on the saint Sisinnios panel (fig. 8).

Such is (was?) the square colored inlaid stone slab from the entrance to the grand Baal Temple in Hatra (Iraq). ${ }^{66}$ In the center of the radiating composition remains but a circular void: the eye in question. There was no trace of it left: was it destroyed as soon as it was found in modern times or when seen in Antiquity? Or was it never made by the fearful sculptor? In a circle around it are set a snake, a running ibis (?), a scorpion with the characteristic sting of his tail turned up, a jumping dog, a bird of prey and a man with a chisel and a hammer ready to hit; all six are intent on attacking and piercing the fateful eye.

The motif is not only found in pagan context. The mid-3 $3^{\text {rd }}$ century synagogue of Dura Europos (Syria) was painted all over its interior walls and also inside the coffers of its ceiling. These carried charming, prophylactic pictures of garlands, flowers, fruit, girl's heads crowned with flowers, running animals, but also two instances of an Evil Eye attacked. One is pierced by three daggers and two snakes, while a big bug approaches from underneath. The other plaque has a centipede sitting on the lid of the eye, while two lighted lamps fight off the evil darkness, their oil dripping on it, and a curved copper-colored mirror is held up to it in the way cunning Perseus turned

64 ...except by a most ill-disposed artist, who would have run off immediately and whose work will not easily have survived through time and man's defense against the maleficent figure!

65 The slab here discussed is kept in Chicago (Parrot 1960, fig. 358a; Donceel-Voûte 2014, 361-364 and fig. 21). The fact that it is made of clay and molded implies that there could have been many more plaques of this type used in and outside the temple, where excavators have met with a number of other series of figured scenes, most of which are of a propitiatory iconographic type.

66 Donceel-Voûte 2014, 361-368, fig.15-21 for the Defeat of the Evil Eye in Hatra and, infra, in Dura Europos. 
Medusa's killing look against herself with his shield. ${ }^{67}$ The fact that the motif is not by an entrance but on the ceiling, directly under the roof, has, of course, to do with the protection of the whole sacred space of the building.

The challenge consists in stopping the roving eye(s) of the Evil One from fixing on its prey. ${ }^{68}$

In the newly-discovered Mithraeum, under one of the two early Christian churches in Huwarte, North of Apamea on the Orontes (Syria), the extant wall paintings carry a scene which greatly contributes to our topic (fig. 16). The dark Evil One has been cornered by the solar god Mithra himself, or one of his companions, who is holding two chains tied to both wrists of his foe. A clue to its identity is its double head, each head looking a different way. This is typical of the worst evil: Envy / Invidia / Baskania / Phthonos ${ }^{69}$.

Never satisfied the roving eye/s of the envious one, the phthoneros, is/are constantly looking for a new prey, on all sides. Consequently, the defense set up against it must also have eyes everywhere. This is where hybrid guards, with a variety of orientations ${ }^{70}$, with several pairs of eyes in or on their heads or in their wings (angels), or running one way while looking the other, or pairs or groups of keepers, become fully understandable: the attack can come from anywhere and the counter-attack must react adequately.

In the Huwarte Mithraeum, while the grotesquely naked Envious One crouches indecently in the scene's left corner, the one who has mastered him is standing in a cool contrapposto, exquisitely dressed, in sumptuous emerald greens and peach pinkhued crimson, ornamented with gold bands set with big red or green cabochon gems. His great honey-coloured stallion is equally elegantly fitted with trappings hung with golden jewels. This show of riches carries a message which is one of the clues of the scene: man and beast are rich, that means mighty, mighty enough to wage this battle and others, and come out of them victorious. In this probably late $3^{\text {rd }}$ or early $4^{\text {th }}$ century monument Mithraism makes itself attractive, before Christianity wins the race.

67 See Donceel-Voûte 2014, 361-368 and here note 31; the Gorgon's dying head and gaze is another extremely frequent Graeco-Roman apotropaion, used to ward off evil and trickery mainly in public and domestic space.

68 Needless to underline: the motif of the evil eye's threat remains vivid and topical both in literary and iconographic and filmic creation: George Orwell's "Big Brother is watching you" in Ninety EightyFour, Sauron's eye in J.R.R. Tolkien's Lord of the Rings are but two of many examples. Most mass surveillance systems are experienced as an evil intrusion, a capturing of private life.

69 This name for Envy is also found associated with the terrible Gello / Alabasandria fought by saint Sisinnios in the Bawit painting previously discussed: Dunbabin/Dickie, 1983. The Huwarte Mihraeum was first published in colour by Gawlikowski 2002, 32-35.

70 As noted above in §I.1. 


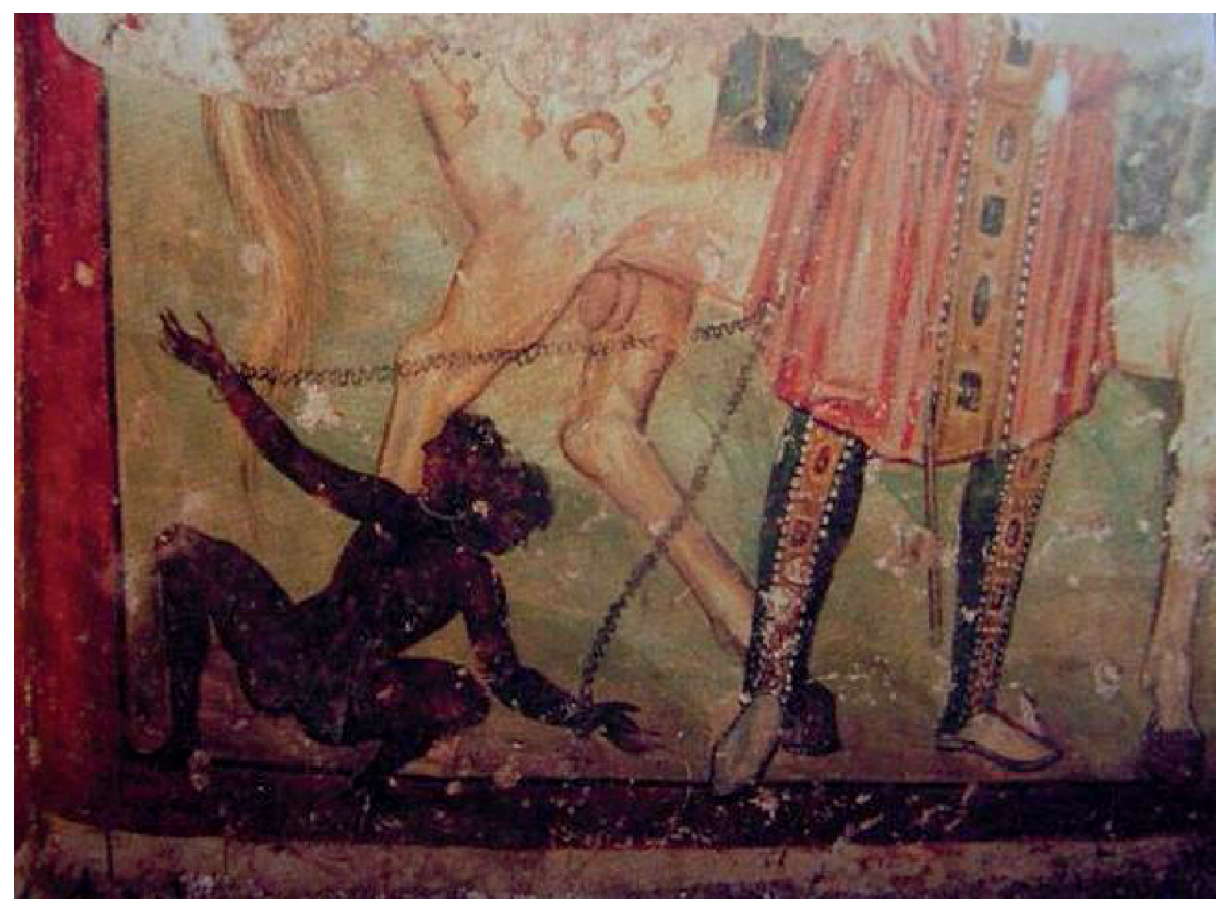

Fig. 16: Evil Envy-Baskanos chained by Mithras; wall-painting of Huarte Mithraeum (Syria). (Gawlikowski 2003, 35).

As for the double-headed Evil One, such as in Huwarte, iconography has developed a perfectly targeted strategy to outdo it. In a precious little mosaic panel from the Djekmedje outskirt of Antioch on the Orontes - now in the Antakya museum - a 'lucky hunchback' takes part in the counter attack against the Evil Eye. ${ }^{71} \mathrm{He}$ is turning away from the dreadful, though dying, gaze of the Eye, but the back of his head carries a second face, somewhat masklike with a pointed nose, turned towards the Eye.

These eyes behind his head become one of the attributes of the Virtue of Prudentia, cautious Wisdom, as we see her personified, for instance, in the Vatican Loggie by Raphael. She is double-faced, with eyes in the front and back (masklike), with a rear-view mirror and the Gorgoneion on her chest, so as to see and protect on all sides. So that Prudentia may also be able to see in the dark, a putto holds up a torch here; elsewhere she will have an owl, like Athena-Minerva and the Bawit Sisinnios for example (fig. 8).

71 Ultimately Donceel-Voûte 2014, 355, 363, fig. 16. 


\subsection{The Deadly Sins, the Vices and Where and How They are Made to End up}

Artists will over and over again use such iconographical strategies with great efficiency.

The further history of visible Evil, with devilish Envy being its main incentive and mark, will find - or need to find - no replacement for those emblematic roving eyes, be they in two different heads (as in the Mithraeum of Huwarte, fig. 16) or in one face with two divergent eyes which is a subtler material statement - and therefore often missed by the public.

Indeed, the devil, in the guise of a young girl (Artemisia, Diocletian's daughter, according to the legend), fought back by Saint Cyriacus, in the Heller Triptych by Meister Mathis Neithart Gothart, named Grünewald, has not only grabbing hands, a cursing mouth, a lashing tongue which the saint pushes back, but above all divergent eyes: one avidly staring to the left and the other to the right, from the corner of the eye. ${ }^{72}$

The open mouth but with a lashing tongue, snake-shaped, is similarly to be found in Giotto's Invidia in the Arena chapel, Padova; it combines with her grabbing hand which even reaches out of the frame, for identifying her monstrous, flaming, unquenchable, ever-hungry, discontented, self-destructive, devilish desire. The age-old attributes of jealous evil are recycled as attributes of this specific personification of a major Vice.

Invidia, indeed, the greed for another's belongings and bliss, is commonly understood since Antiquity as the trigger of most evil. This is stated again quite clearly in a masterly mise en scène by one of the great iconographers of modern times, Otto Dix. His oil painting of the Seven Deadly Sins ${ }^{73}$ clearly shows the little personified Envy to be the leader of the gang of all the deadly sins, who bring only desolation and barren wasteland where they pass. He has two greedy globular eyes looking in different directions, a Hitler moustache, and his grabbing hands pinch barren Avarice's back, which he is riding. The terrible vice and the Deadly Sin are identified by the same traditional iconographic vocabulary, but brilliantly renewed.

72 Staatliche Kunsthalle Karlsruhe 2007, 137-139. The young girl seems to me to be characterized as possessed specifically by an envious devil, because of her not just revulsed but divergent eyes. The tongue sticking out and the crooked fingers are both in the tradition of the iconography of Invidia and medically observable in the 'Great hysterical nevrosis' identified in a number of works of art, by Charcot/Richer 1972.

73 The oil painting is kept in the Staatliche Kunsthalle in Karlsruhe; the preparatory drawing, also dating to the fateful year 1933, is equally extant and kept in the Galerie der Stadt in Stuttgart, who lends it to travelling exhibitions. See Karcher 1992, 180-181: the divergent eyes of the Hitler-like little Envy are present in both stages of the work. 
However, what the $20^{\text {th }}$ century dares evoke in a two-dimensional painting letting Evil loose, was previously systematically and strategically set in a battle and victory scene. Thus, both Meister Mathis alias Grünewald and Giotto show Envy and other personifications of Evil defeated and disposed of. Saint Cyriacus is calmly closing the possessed girl's mouth and thus containing the devil. As for Giotto's Invidia, neither she nor the other Vices on the north side of the Scrovegni chapel are left to roam free. They all look towards the entrance, that is towards us coming in; but, doing so, they also look towards the scene of the Last Judgment in which they will be taken up, as in a continuous narration. The Virtues are on the south side; they are led by an ecstatic and airy SPES followed by KARITAS ${ }^{74}$, who both lift up their arms to float into the procession of the Elect on the western façade fresco, ad dextram Domini. On the north side the Vices are also looking towards the western façade, but they will end up with the ugly Damned as they progress straight into dark, chaotic inferno.

This is one more visual strategy for vanquishing Evil and keeping it out of the way. Devilish, evildoing figures are caged, shut up in a dark enclosure.

The Notre-Dame de Paris medallions, on the dado of the main façade's central portal, have integrated the solution of caging Evil in a subtle way. The Vices are each set in a roundel. They wriggle inside in chaotic action but the particularly deep and smooth sides of their well-like setting make them look trapped inside. On a level right above them stretches the line of the noble Virtues, in lower relief. Peacefully seated on a throne, casually holding a round shield with their emblem, their status is enhanced by the airy lobate arches that enshrine them. As their corresponding Vices are situated under their feet, one can read the whole composition as a multiple calcatio.

The funerary parekklesion of the Christ-Saviour-in-Chora church (Kariye Djami) in Constantinopel offers a particularly elaborate Last Judgment and Apocalypse composition in the vault and adjoining conch at its east end. Under the Rolling up of the heavens, the Deesis with the heavenly tribunal and Christ in majesty, the fiery red enclosure of Hell stretches towards the south wall (fig. 17). There, four near to square spaces, akin to neat boxes, await the damned, totally naked though with different hairdos. Here they fade away in a bleak mist; there they freeze endlessly in an extreme, blue, cold; in a third cell they writhe about under swarms of worms from top to bottom, while they die over and again in the extreme dark red heat of the cell on the lower right.

74 Caritas, second of the Theological Virtues, is facing the awful Invidia on the opposite side of the nave, each Vice thus checked by its corresponding Virtue, as in Prudentius' Psychomachia text. Giotto has set those seven battles against Evil to be fought during man's lifetime, in a wider, universal and final scope, developing a four-dimensional drama, as he links it to its final outcome at the end of Time. 


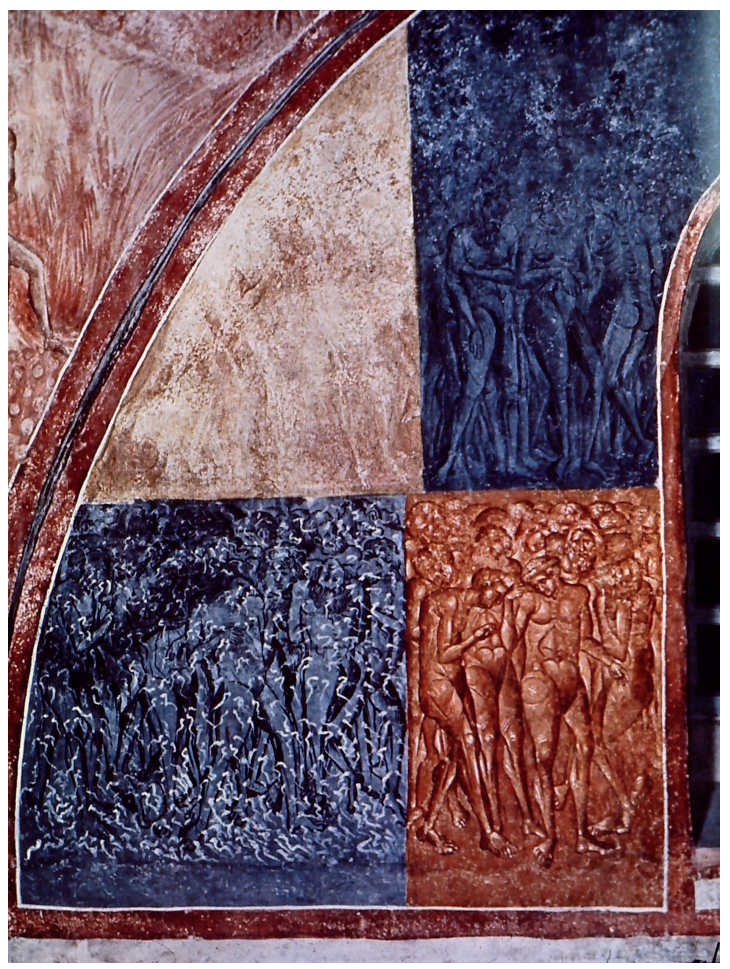

Fig. 17: The Damned caged in the Last Judgment scene, side-chapel of the Christ Saviour in Chora church, Istanbul. (@Donceel 1977).

The recurrent use of such an imprisonment in a dark dungeon-like enclosure is to be found in many Last Judgment scenes in both Eastern and Western traditions. ${ }^{75}$ The damned souls, in the shape of little human figures, not always naked, are on our right side when we look at them but, inside the picture, they are on the left side of the divine judge, ad sinistram. This sinister side, plunging towards Hell, is a closed-off area with a sinuous contour, sometimes black, more often red and suggesting flames but also blood and suffering of those that 'have not deserved better'. The area is clearly defined as separated from the soft light, the pastel colors, the upward movements and the golden radiance on the right hand of God.

75 Hughes 1968, Part 1 concerns the last Judgment, where the souls are directed, as the author puts it, to "the Mansion" or to "the Dungeon" (pp. 13-46). The "dungeon" is truly the Hell as observed in both in Eastern and Western traditions: massive, cut off from the rest of the scene by complex lines and contrary colors (pp. 159-201); the term equally suits the device of the deep circular frames inside which are kept the Notre Dame Vices. 
The strategies of defense and attack of Evil as we have observed them are limited in number but their principles are universal and their iconographies multiform. Although the typology we have been able to set up and present here is based on artefacts from a variety of chronological and topographical horizons, it manifests that the semantic field of Evil and the contrasting and colorful images that belong to it are written in a rich and fundamentally common language.

\section{Bibliography}

Alpago-Novello, Adriano/Beridze, Vahtang/Lafontaine-Dosogne, Jacqueline et al. (1980), Art and Architecture in Medieval Georgia (Publications d'Histoire de l'Art et d'Archéologie de I'Université catholique de Louvain XXI), Louvain-la-Neuve.

Amiet, Pierre (1977), L'art antique du Proche-Orient, ed. L. Mazenod, Paris.

Bradshaw Aitken, Ellen/Fossey, John M. (eds.) (2014), The Levant: Crossroads of Late Antiquity/ Le Levant: Carrefour de l'Antiquité tardive, Leiden/Boston.

Charcot, Jean-Martin/Richer, Paul (1972), Les démoniaques dans l'art, Amsterdam.

Clédat, Jean (1904), Mémoires de l'Institut Français d'Archéologie Orientale. Vol.12, Cairo.

De Ruyt, Franz (1934), Charun, demon étrusque de la mort, Rome.

Donceel-Voûte, Pauline (1983), “La pierre d'aigle et l'aigle au bijou”, in: Mosaïque. Recueil d'hommages à Henri Stern, Paris, 115-121.

Donceel-Voûte, Pauline (1988), Les pavements des églises byzantines de la Syrie et du Liban. Décor, archéologie et liturgie, Louvain-la-Neuve.

Donceel-Voûte, Pauline (2014), "Barrer la route au Malin. Une typologie des stratégies utilisées. Images et signes à fonctionnement sécuritaire sur support fixe dans l'Antiquité tardive”, in: Ellen Bradshaw Aitken and John M. Fossey (eds.), The Levant: Crossroads of Late Antiquity/ Le Levant: Carrefour de l'Antiquité tardive, Leiden/Boston, 347-400.

Dunand, Françoise/Zivie-Coche, Christine (2004), Gods and men in Egypt, 3000 BCE to 395 CE, Ithaca/London.

Dunbabin, Katherine (1991), “Inbide calco te. Trampling on the Envious”, in: Ernst Dassmann and Klaus Thraede (eds.), Tesserae. Festschrift für J. Engemann, Jahrbuch für Antike und Christentum Ergänzungsband 18, Münster, 26-35, Tff. 1-7.

Dunbabin, Katherine/Dickie, M.W. (1983), “Invidia rumpantur pectora. The Iconography of Phthonos. Invidia in Graeco-Roman Art”, in: Jahrbuch für Antike und Christentum 26, 7-37.

Fauth, Wolfgang (1999), “Der Christliche Heilige des Sisinnios-Typs im Kampf gegen eine vielnamige Dämonin”, in: Vigiliae Christianae 53/4, 401-425.

Gawlikowski, Michel (2002), “Les mystères du culte de Mithra”, in: Le monde de la bible 149, 32-35. Greenfield, R.P.H. (1989), "Saint Sisinnios, the Archangel Michael and the Female Demon Gylou: the

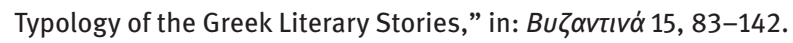

Guide-Book to the Iraq Museum (1976), 3rd edition, Baghdad.

Hughes, Robert (1968), Heaven and hell in western art, New York.

Kaplan, Ayda (2013), Le lectionnaire de Dioscoros Theodoros. Décor, calligraphie et liturgie, preface P. Donceel-Voûte, Bruxelles.

Karcher, Eva (1992), Otto Dix 1891-1969, Cologne.

Kesjakova E. (1989), "Synagogue antique de Philippopolis”, in: Arheologija (Serbian), 31/1, Sofia, 20-33. 
Kitzinger, Ernst (1970), "The threshold of the holy shrine: observations on floor mosaics at Antioch and Bethlehem", in: Patrick Granfield and Joseph A. Jungmann (eds.), Kyriakon: Festschrift Johannes Quasten. Vol. II, Münster/Aschendorff, 639-647.

Kraus, Thomas (2018), “Archäologische Artefakte mit griechischem Psalm 90 in apotropäischer Funktion”, in: Wilfried E. Keil, Sarah Kiyanrad, Christoffer Theis and Laura Willer (eds.), Zeichentragende Artefakte im sakralen Raum. Zwischen Präsenz und UnSichtbarkeit, Berlin/Boston, 121-138

Krause, Karin (2000), “Darstellungen der Kreuzesverehrung auf palästinesischen Pilgerampullen” in: Mitteilungen zur spätantiken Archäologie und byzantinischen Kunstgeschichte 2, 9-51.

Lascaux, Gilbert (1973), Le monstre dans l'art occidental, Paris.

LIMC (Lexicon Iconographicum Mythologiae Classicae) (1981-1999). Vol. I,1-2-VIII,1-2 and Indices, Paris/Zurich.

Michalowski, Kazimierz/Corteggiani, Jean-Pierre/Roccati, Alessandro (1968/1994), L'art de l'Égypte, Paris.

Napoleone-Lemaire, Jacqueline/Balty, Jean-Charles (1969), L'église à atrium de la grande colonnade. Fouilles d'Apamée de Syrie I,1, Bruxelles.

Parrot, André (1960), Sumer (Coll. L’Univers des formes), Paris.

Parrot, André (1961), Assur (Coll. L'Univers des formes), Paris.

Parry, V. J. (1977), "Warfare”, in: P.M. Holt, Ann Lambton and Bernard K.S. Lewis (eds.), The Cambridge history of Islam, . Vol. 2B, Cambridge/ London/ New York/ Melbourne. , 824-850

Playoust, Catherine (2014), "The Beauty of Jesus and His Twin: Redirected Erotics in the Acts of Thomas”, in: Ellen Bradshaw Aitken and John M. Fossey (eds.), The Levant: Crossroads of Late Antiquity/ Le Levant: Carrefour de l'Antiquité tardive, Leiden/Boston, 35-63.

Ross, Marvin C. (1962), Catalogue of the byzantine and early mediaeval antiquities in the Dumbarton Oaks Collection. Vol.1, Washington.

Staatliche Kunsthalle Karlsruhe (2007), Grünewald und seine Zeit, Karlsruhe.

Van Moorsel, Paul (2002), Le monastère de Saint-Paul près de la mer Rouge, Mémoires de l'Institut Français d'Archéologie Orientale. Vol. 12, Cairo.

Walter, Christopher (2003), The warrior saint in Byzantine art and tradition, Aldershot.

West, D.R. (1991), “Gello and Lamia: Two Hellenic Daemons of Semitic Origin”, in: Ugarit-

Forschungen 23, 361-368. 